\title{
鎌倉文庫の単行本出版目録
}

Natsuko OZAKI(尾崎名津子 : Associate Professor, Hirosaki University)

四 ntkozk1126@gmail.com

(日本)弘前大学人文社会科学部准教授。日本近現代文学。主著に゙織田作之助論〈大阪〉表象という戦略』(大 阪：和泉書院, 2016)、編著に『織田作之助女性小説セレクション怖るべき女』(東京：春陽堂書店, 2019)、共編 著に金ヨンロン·尾崎名津子・十重田裕一『「言論統制」の近代を問いなおす一検閲が文学と出版にもたらしたもの』 (東京：花鳥社, 2019)など。

\section{The Book Catalog of Kamakura Bunko}

This report contains the latest edition of a catalogue of books published by Kamakura Bunko. The company's primary data are also analyzed in order to clarify the type of business strategy Kamakura Bunko developed as a company, and its success or lack of success in pursuing it.

It was writers such as Yasunari KAWABATA and Masao KUME who managed Kamakura Bunko, which was quite rare in the history of Japanese publishing. A consideration of the history of Kamakura Bunko will provide a useful perspective on the relationship between modern writers and the publishing industry. The purpose of this report is to provide the basic data that can facilitate this.

Keywords Kamakura Bunko(鎌倉文庫), Period of Occupation(占領 期), Literary Publishing (文学出版), World Literature(世界 文学) 
1 高見順 $「 「$ 鎌倉文庫」の 記録一重役作家時代一」 (『文学界』第9巻第 9 号, 1955.9), p.68.

2 久米正雄「我が鎌倉文庫 の記」(涉澤秀雄(同人代 表)『じふろくささげ』 黄楊書房, 1948.2), pp.128 -135 .

3 前揭注 1, p.69

4 前揭注2, p.138

5 伊藤玄二郎「鎌倉文壇史 余滴一「鎌倉文庫」の周 辺」( $(\mathbb{P}$ 月刊公論』第 23 巻 第9号, 1990.9), p.62.

\section{1 はじめに一一鎌倉文庫について}

1945年5月1日、神奈川県鎌倉市に貸本屋・鎌倉文庫が開店した。当時、アメリ 力軍が相模湾から上陸するという噂が鎌倉に流れており、これを耳にした鎌倉在 住の作家たちが、疎開ではなく「籠城」をするための資金稼ぎを検討した結果とし ての、「作家による貸本屋経営」だった。三方を山、一方を海に囲まれた鎌倉は、 山側に古くからの洞窟が複数点在するが、鎌倉文庫で中心的な役割を果たした高

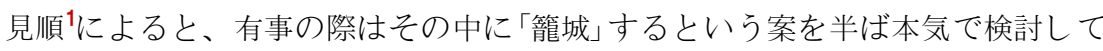
いたという。鎌倉ペンクラブの会長だった久米正雄のもとに、高見と小林秀雄が 貸本屋経営の相談を持ちかけたのが1945年4月上旬だった。

久米、高見に加えて川端康成、中山義秀が貸本屋の世話役となったが、本の供 出者は彼ら以外に里見弶、島木健作、小林秀雄、中村光夫、吉屋信子、長田秀 雄、松井翠聲、岡田眞吉、福永恭助、夏目伸六などだった。さらに、開店日は 「手伝い」として小島政二郎、大仏次郎、永井龍男、林房雄といった他の鎌倉在住 作家に加え、清水崑、横山隆一という漫画家も参加した。

久米正雄にによれば、店舗については川端康成の妻が談判で一役買った結果、 「八幡前」(鶴岡八幡宮前)の若宮大路という好立地にある、棚、陳列台、硝子函が 揃った玩具屋を借りることに成功し、貸本は「最低十銭から、最高一日五十銭」と いう価格設定にした。顧客は鎌倉近辺の主婦と横須賀にいた海軍の関係者が目立 ち、会員数は開店から1ヶ月で1,000人近くになったという。

敗戦直後の 8 月下旬に、大同製紙の関係者から鎌倉文庫に出版事業への誘いが あったようである。高見は「D製紙会社の重役から、「鎌倉文庫と提携して出版会 社を「はじめたい」といふ」話が久米正雄のところへ持ち込まれた」と記録してい る。久米は8月 15 日から「十二三日経つ」た頃に、面識のない人物から以下のよう な書状が届いたと述べている。

鎌倉文庫の方々が中心になつて、一つ出版をおやりになりませんか。当 万には手持の紙と、残存の印刷設備とがありますから、若し其気があるな ら、いつでも御相談に応じます。

実は小生は、鎌倉に別宅を持つてるる者で、その通りがかりに、諸兄が 自ら身を挺して、店務に精励されてるるのを見、感激して、此の人々とな ら、事を共にしてもいいと感じ、突然乍ら、此の提言をする次第です。ど うか自分たちの文化日本再建の努力に、参加したい希望を信じて、即刻、御 返事下さい。待つて居ります 4 。

最初に申し出があった具体的な日付は8月29日、「D製紙会社の重役」は荒川喜 久雄という人物だという指摘がある5。この申し出には、戦時下に溜め込んでい 
た物資(印刷用の洋紙)の効率的な商品化を目論んだ荒川氏の意図を読み取ってよ いものと考えられ、高見の誘いで鎌倉文庫の出版部に勤めた巌谷大四6は「実際 は、紙屋の甘言にのせられて、見事に文士が利用された」と総括している。

出版社創業の話は進み、株式会社「鎌倉文庫」が9月14日に発足した。事務取締

6 巌谷大四「「鎌倉文庫」 雑記」(『非常時日本」 文壇史』中央公論社, 1958.9), p.159. 役社長 - 久米正雄、常務取締役・川端康成、岡澤一夫 (大同製紙)、取締役・高見 順、中山義秀、里見弴、大仏次郎、荒川喜久雄(大同製紙)、川北警二(同)、長谷川 隆士 (同)という体制で、社屋は東京駅前の丸ビルの6階にあった、中央公論社の 事務所を借りた。のちの1947年4月20日に日本橋茅場町の白木屋ビル2階に転居し た。

以下に見る実際の出版物を見る限り、発行者は「岡澤一夫」となっているか ら、実務は岡沢が一手に引き受け、作家たちはいわば原稿集めにかり出されたと 言える。出版社・鎌倉文庫は、現在では文芸雑誌『人間』や『婦人文庫』、『社会』、 『ヨーロッパ』、文芸往来』といった雑誌の出版で知られる。『人間』は戦中に河出 書房の『文藝』で編集に携わっていた木村徳三が編集長となり、三島由紀夫、武田 泰淳、中村真一郎、加藤周一、野間宏、木下順二らの作品を積極的に掲載した。 この華やかさゆえに、鎌倉文庫の出版事業については雑誌に注目が集まる向きが ある。一方で、単行本出版の全容については未だ詳らかでない。

本稿では、この鎌倉文庫の単行本出版の全容解明を目指し作成した目録を示 す。また、それを通して鎌倉文庫の出版事業の特色や、占領期の出版事情の一端 を明らかにしたい。

\section{2 出版事業の特色}

以下では、『人間』の「出版だより」欄の記述を参照しつつ、鎌倉文庫の出版事 業の展開を追っていきたい。「出版だより」は雑誌の創刊号から、目黒書店が発行 するようになる1950年1月号まで断続的に掲載され、特に1946年と47年はほぼ毎 号確認できる。

まず、『人間』1946年1月号では「現代文学選」と「大衆文学選」の刊行開始を告げ るとともに、進行中の企画として「国木田独歩全集」、「世界文学選」、「青春の書」、 「現代随筆選」、「高浜虚子散文全集」が構想されている旨の報告がある。このう ち、「現代随筆選」と「高浜虚子散文全集」は実現しなかった。続く『人間』同年 2 月 号では、「杪国民に対する贈物の用意」があるとして、横山隆一のフクチャンシ リーズを刊行することや、「学童課外絵本ともいふべき「一茶絵本」「芭蕉絵本」「無 村絵本」」、さらに「世界名作童話」が刊行予定とある。このうち、現物が確認でき るのはフクチャンシリーズ(一部)と『一茶絵本』(1946年10月)のみである。 
7 木村徳三「『人間』編集 長として」(『彷書月刊』 第2巻第8号, 1986.8), p.10.
このように、当初は文芸書においてはいわゆる円本のように新作の刊行では なく既に知られた作品の再刊が目立ち、新規のものとして子ども向けの書物に意 が注がれていた。また、『国木田独歩全集』は結果的に完結できなかった。これ について木村徳三は次のように証言している。

国木田独歩の全集ですか?あ机は久米さんの公私混同。国木田さんの息子 さんが鎌倉文庫に来て、「どうしても出してくれ」と言うので。

ところが独歩全集は、やがてお荷物になりました。だから結局、完結も いたしませんでした。何故あの時期に独歩全集を出さなきやならないか と、皆さんがけげんに捻思いになるのも当然でしょうね7。

現代文学選(監修者不明)、大衆文学選(監修・吉川英治、長谷川伸、加藤武雄、 木村毅、大佛次郎、久米正雄) は先に述べた通り円本、即ち改造社の現代日本文学 全集のアイディアを戦後において復活させたものだと言える。新規のものとし て青春の書と世界文学選を指摘できよう。前者は日本文学と海外文学を〈青春〉を 鍵語として等し並みに並べようとした企画である。これに加えて、単独の単行 本の中に洋の東西を問わない翻訳書が多数確認できること、これらの翻訳書が以 前の訳文ではなく新訳を多く採用していること、あるいは、アメリカでの人文 学系の論文、評論を抄訳した「アメリカ文庫」がコンスタントに刊行されていた ことを鑑みると、この出版社が単に「文士の出版社」と呼んで済む企業なのではな く、その指向性に特色があることが看取できる。

青春の書について、「出版だより」(『人間』1946年3月)には、「「狭き門」を一言 にして理性の書とすれば堀辰雄氏の「燃ゆる煩」は感情の書と称し得る」、「田中英 光氏の「オリンポスの果実」は肉体の書とでもいふべきであらうか」との予告を出 しているが、実際の刊行時期は1946年5月(『燃ゆる煩』)、8月(『狭き門』)、11月 (『オリンポスの果実』)とばらつきが見られる。このようなかなり先走った予告 は「出版だより」内に散見される。1946年4月号でも青春の書の予告として『ポー ルとヴィルジニー』(山内義雄訳)、『カール・ハインリッヒ』(成瀬無極訳)、犬養 健の新作も含めた短編集が挙げられているが、そのいずれも実現を見ていな い。

世界文学選は1946年7月の「出版だより」で「第一期として、米、英二十篇、 仏、露、中国、独の各国十篇、南、中、北欧十篇、計七十篇を選出した」とあ り、その具体的な内容は明らかでないが、読者が「世界各国の文学の流れを系統 的に読み進むうちに自ら人間の精神的発展の姿を汲み取ることが出来るやうな」 作品を選んだことが告げられている。このことからも、鎌倉文庫の出版事業に おける世界文学志向が窥える。しかし、世界文学選と銘打った出版物は巴金『家』 (1948年8月)の一冊に留まっている。 


\section{3 印刷地について}

これまでのデータ採取の過程で、占領期出版の事情が現物から少しずつ見え てきた。印刷は主に大同製紙の系列企業である帝都印刷株式会社が請け負ってい たようだが、そのかぎりではない。

注目すべきところとしては、北海道での印刷と出版である。最も早い時期の ものとして、先述の青春の書第2弾として刊行されたアンドレ・ジイド『狭き門』 (目録番号25)がある。また、最も遅い時期のものとして久米正雄『風と月と』(目 録番号84)がある。出版物を根拠とするかぎり、鎌倉文庫は1946年夏から47年秋 あたりまでのごく短い期間に札幌に「支社」を置き、東京で先行して出た単行本を 「再版」として再刊するとともに、支社のみからの刊行も行っていたことが分か る。なお、占領期における北海道での出版についでと、ケーススタディとして 高見順『今ひとたびの』の出版と検閲について9は拙稿で既に述べたため、本稿で はこれを繰り返さない。

北海道以外でも、東京都西多摩郡、栃木県足利市など複数の印刷会社を頼って いたことが分かる。用紙統制が続く占領期にあって、刷ってくれるところがあ ればどこでも印刷してもらう方針だったと推察される。殊に、里見弶『蝉の拔殼』 （1949年7月、目録番号159）の印刷は「北原春夫」氏が社主を務める「文壽堂印刷株式 会社」で行われたが、この所在地「横浜市金沢区堀口八八」が目を惹く。鎌倉市と も直に接している横浜市金沢区は、神奈川県内だと現在でも印刷会社が比較的多 く所在しているが、東京都板橋区に比べれば規模の大小にかなり差がある。ま た、鎌倉文庫の出版物でも文壽堂印刷で刷られたのは該当本だけであるので、こ の印刷は鎌倉文庫関係者の地縁に拠っていると推察することもできる。

他にも、目録化することで印刷所の変遷(取引先の拡大と縮小)を辿ることが でき、それにより鎌倉文庫の出版事業の盛衰を様々に検討することが可能にな る。

\section{4 目録について}

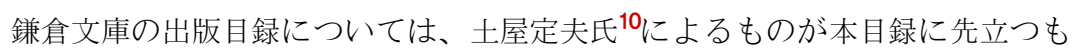
のとしてある。本目録ではそのリストを踏まえつつ、適宜情報を更新した。ま た、立項は土屋氏のリストに印刷日、版数、装幀者、発行者、発行者住所、印刷 者、印刷者住所、価格、備考を加えた。また、本目録の作成作業にあたっては、 現物に基づくデータ採取を旨としている。本稿の目録において印刷日欄が空闌に なっているものは、土屋氏のリストにはデータが記載されているが、これまで 
11 高見順「鎌倉文庫につ いて」(高見順『人生の 周辺』平凡社, 1957.5), p.246.
の調査で現物が確認できていないものである。この点については引き続き調査 を進める。

鎌倉文庫の終焉については関係者の証言に基づくと、雑誌『人間』だけは木村 徳三編集長のポケットマネーをつぎ込むなどして発行を続けていたが、ついに 目黒書店に事業を移す形で1949年11月頃に解散を迎えた、という筋になる。一 方、この頃の単行本出版は出版点数が減るものの、「人間選書」を中心に事業は続 いていたことが分かる。解散後については、土屋氏のリストによると「鎌倉文庫 新社」を名乗る出版社が、1950年中に出版活動を行っていた。この点について今 回、出版物の現物をべースにあらためたところ、『脱出』よりも後に刊行された ものとして以下の2点を確認できた。それは、ともに1950年8月15日を発行日と するゴーゴリ／原久一郎訳『『゙ーゴリ書簡集 作者の懺悔』と『マックス・ウェー バー研究』である。両方とも土屋氏のリストに挙がっている。これらは鎌倉文庫 の既刊の出版物を再刊したものと言えるが、発行者が平田富朗(東京都板橋区板橋 町三ノ六四)、印刷者が長谷川隆士(東京都板橋区板橋町三ノ六四(帝都印刷株式会 社）となっており、鎌倉文庫版と装幀が異なる。この刊行の経緯は詳らかでない とはいえ、岡澤の名前がなく、また、岡澤が1947年中に大同製紙から絶縁に近い 独立を果たしたという高見の証言 ${ }^{11}$ を踏まえると、「文士の出版社」たる鎌倉文庫 と「鎌倉文庫新社」とは人員の面でほぼ交わらないものだったと見てよいだろ う。

稿者としては、鎌倉文庫が最後に刊行した単行本は駒田信行『脱出』であると いうことを、改めて強調しておきたい。ただし、これも現時点での調查報告で あり、今後も調査を継続することを最後に付記する。

付記 本研究はJSPS科研費 JP18K12278の助成を受けたものです。また、目録の作成にあたって は、古川晴菜氏、坂田遥氏、稲見ののか氏、後藤展維氏、青山遥香氏、岡本理奈氏の協力を 得ました。この場を借りて感謝申し上げます。

This work was supported by JSPS KAKENHI Grant Number JP18K12278. The following people cooperated in organizing the data; Haruna KOGAWA, Haruka SAKATA, Nonoka INAMI, Noi GOTO, Haruka AOYAMA, and Rina OKAMOTO.

\section{参考文献(Bibliography)}

高見順 (1955) 「「鎌倉文庫」の記録一重役作家時代一」『文学界』第9巻第9号, pp.68-72. Takami, Jun (1955) Kamakura Bunko no Kiroku： Jyuyaku-sakka Jidai. Bungakukai Vol. 9. No. 9. pp.68-72. 久米正雄 (1948)「我が鎌倉文庫の記」，澁澤秀雄 (同人代表)『じふろくささげ』，東京：黄楊書房， pp.120-138. Kume. Masao (1948) Waga Kamakura Bunko no Ki. Jifurokusasage, ed. Shibusawa, Hideo, Tokyo : Kouyou Shobou, pp.120-138. 伊藤玄二郎 (1990)「鎌倉文壇史余滴一「鎌倉文庫」の周辺」『月刊公論』第23巻第9号, pp.60-63. Ito, 
Genjiro (1990) Kamakura Bundan-shi Yoteki : Kamakura Bunko no Shuhen. Gekkan Kouron Vol. 23. No. 9. pp.60-63.

巌谷大四(1958) 「「鎌倉文庫」雑記」，巌谷大四『非常時日本」文壇史』，東京：中央公論社，pp.156-177. Iwaya. Daishi(1958) Kamakura Bunko Zakki. Hijyouji Nihon Bundan-shi by Iwaya. Daishi, Tokyo: Chuo Kouron-sha. pp.157-177.

木村徳三 (1986)『人間』編集長として』彷書月刊』第2巻第8号, pp.7-11. Kimura. Tokuzo (1986) Ningen Henshu-cho toshite, Housho Gekkan Vol. 2. No. 8, pp.7-11.

尾崎名津子 (2020)「占領期の北海道における出版ブーム一鎌倉文庫北海道支社の活動一」『いずみ通 信』第45号. pp.15-16. Ozaki. Natsuko(2020) Senryo-ki no Hokkaido ni okeru Shuppan Boom, Izumi Tsushin Vol. 45, pp.15-16.

尾崎名津子 (2020)「高見順『今ひとたびの』の諸本一メリーランド大学プランゲ文庫所蔵本を中心に一」 『弘前大学国語国文学』第41号, pp.31-51. Ozaki. Natsuko(2020) Takami Jun Ima Hitotabi No no Shohon : Maryland Univ. Prange Collection Shozou-bon wo Chushin ni. Hirosaki Daigaku Kokugo Kokubungaku Vol. 41. pp.31-51.

土屋定夫 (2000)「鎌倉文庫の出版物と参考文献について」『鄉土神奈川』第38号, pp.29-40. Tsuchiva. Sadao (2000) Kamakura Bunko no Shuppan-butsu to Sankou-bunken ni tsuite. Kyoudo Kanagawa Vol. 38, pp.29-40.

高見順 (1957)「鎌倉文庫について」, 高見順『人生の周辺』東京：平凡社, pp.236-248. Takami. Jun(1957) Kamakura Bunko ni tsuite, Jinsei no Shuhen by Takami. Jun. Tokyo: Heibonsha. pp.236-248. 


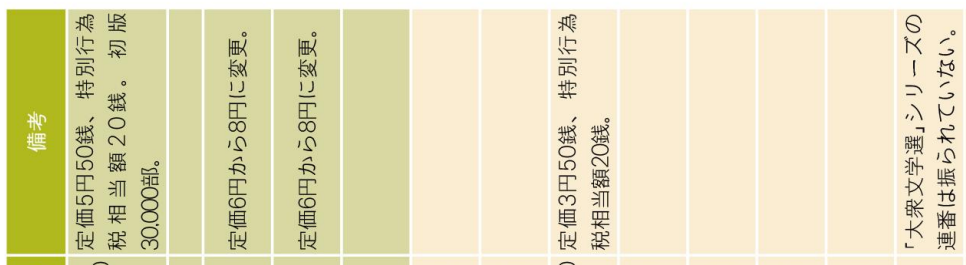

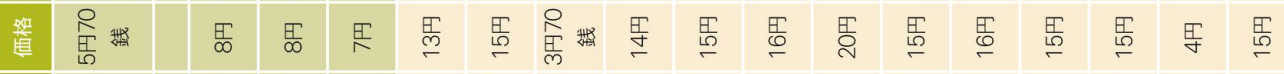

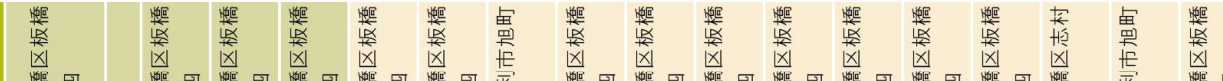

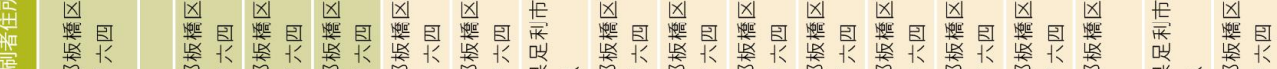

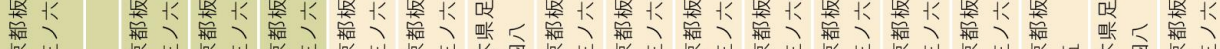

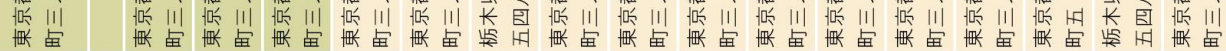

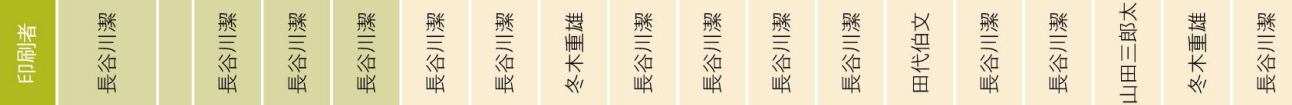

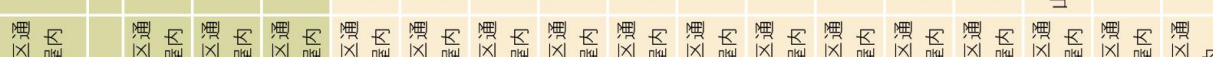

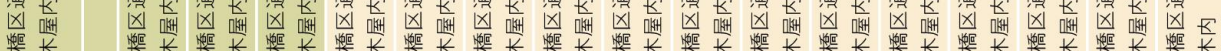

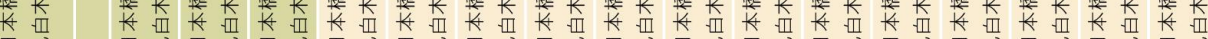

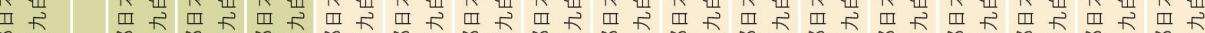

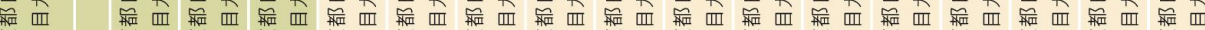
呫

\begin{tabular}{|c|c|c|c|c|c|c|c|c|c|c|c|c|c|c|c|c|}
\hline 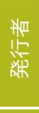 & $\begin{array}{c}\text { K } \\
\text { | } \\
\text { 㐟 } \\
\text { 通 }\end{array}$ & $\begin{array}{l}\text { K } \\
\text { 偡 } \\
\text { 国 }\end{array}$ & 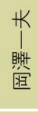 & 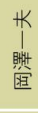 & $\begin{array}{l}\text { K } \\
\text { 䁌 } \\
\text { 国 }\end{array}$ & 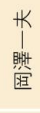 & 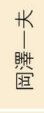 & 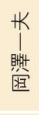 & $\begin{array}{l}\text { 世 } \\
\text { 買 } \\
\text { 盄 }\end{array}$ & $\begin{array}{l}\text { 世 } \\
\text { 貝 } \\
\text { 邀 }\end{array}$ & $\begin{array}{l}\text { K } \\
\text { 罷 } \\
\text { 邀 }\end{array}$ & 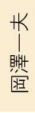 & 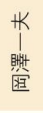 & $\begin{array}{l}\text { K } \\
\text { I } \\
\text { 暊 } \\
\text { 国 }\end{array}$ & $\begin{array}{l}\text { K } \\
\text { 䀝 } \\
\text { 函 }\end{array}$ & 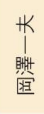 \\
\hline 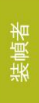 & & & & & & & & & & & & 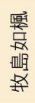 & & & 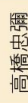 & \\
\hline
\end{tabular}

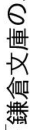

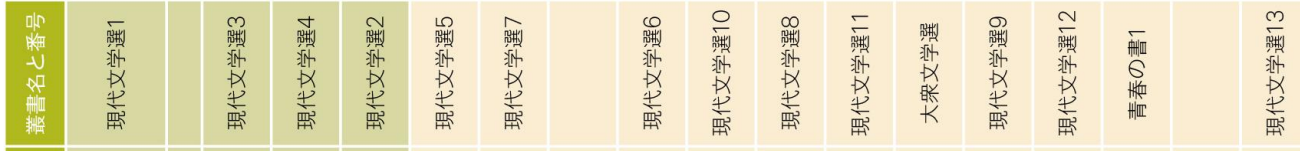

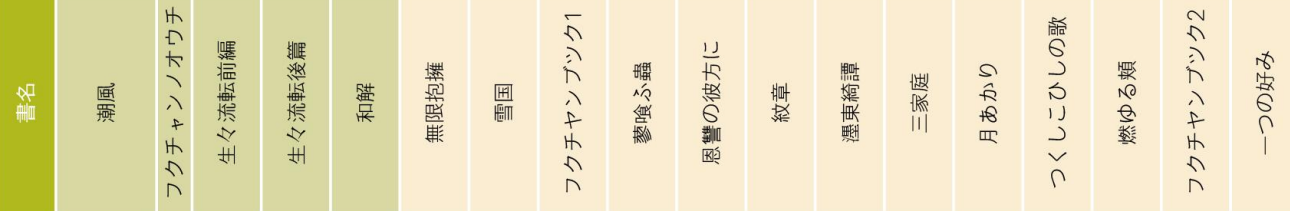

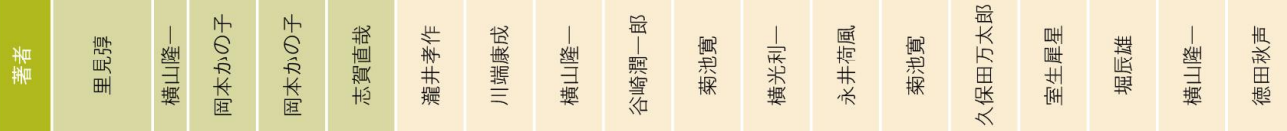

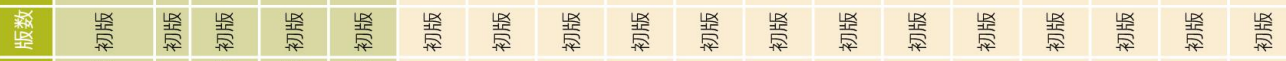

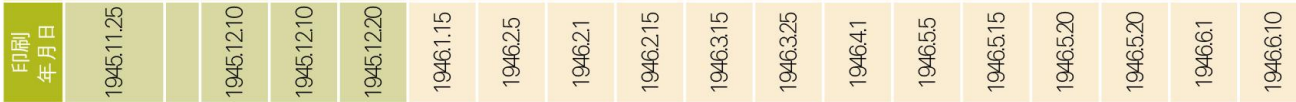

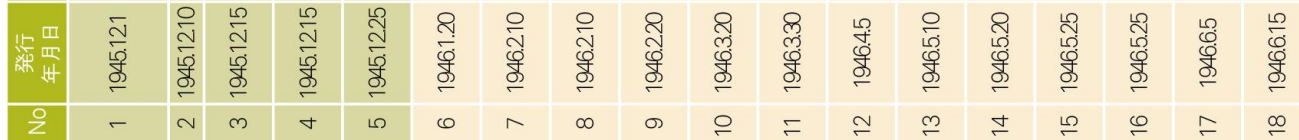




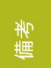

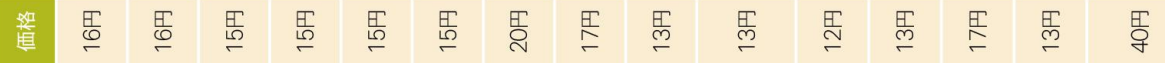

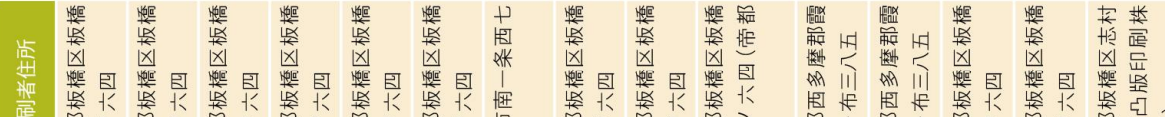

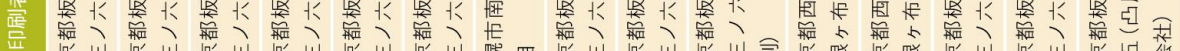

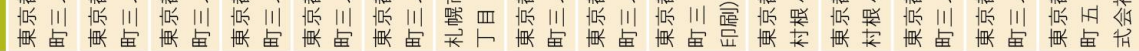

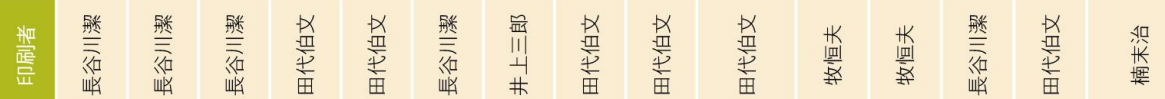

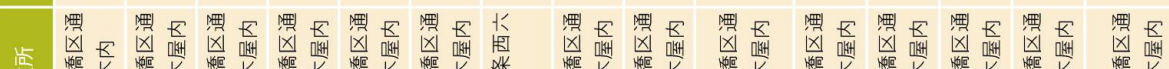

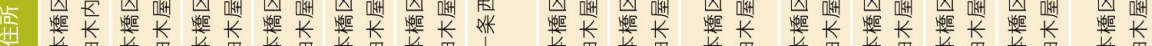

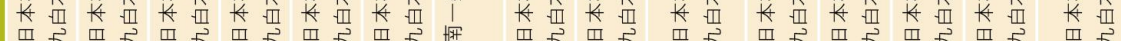

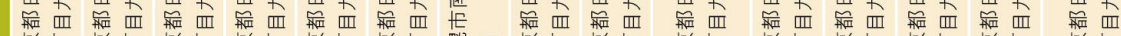

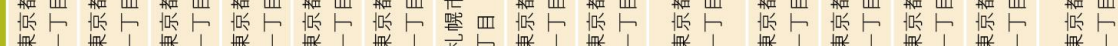

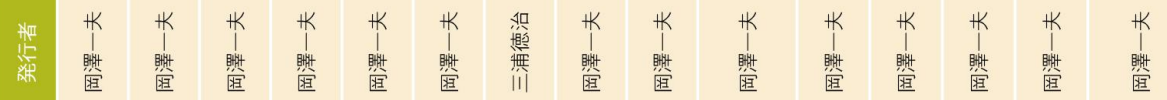

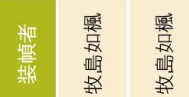

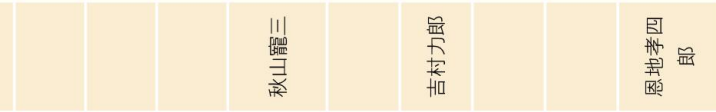

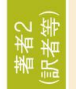

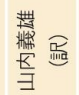

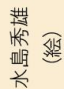

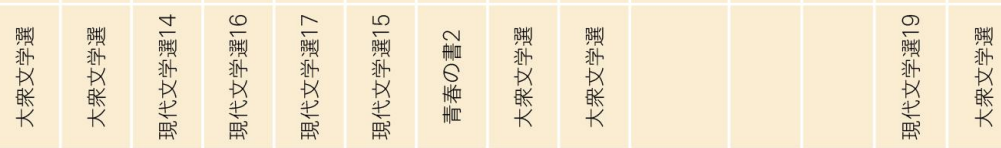

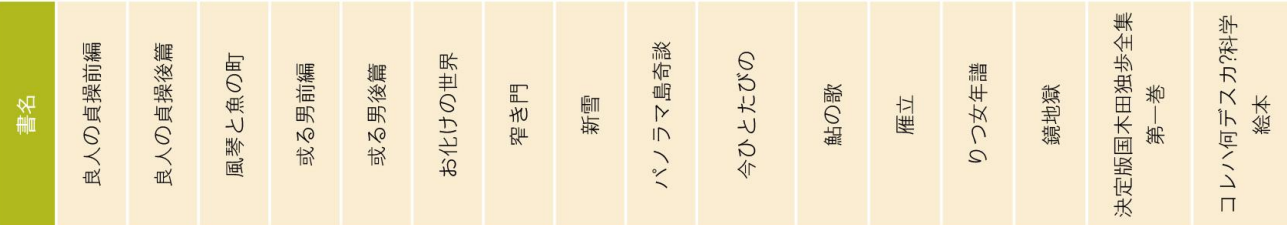

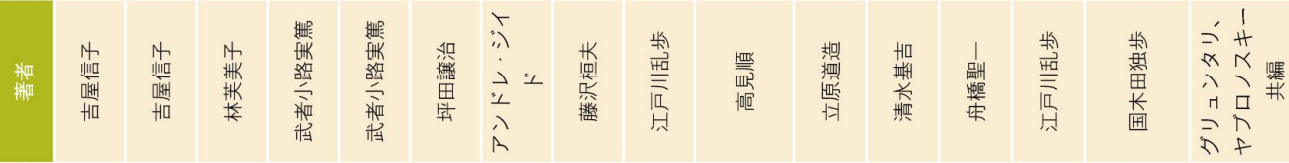

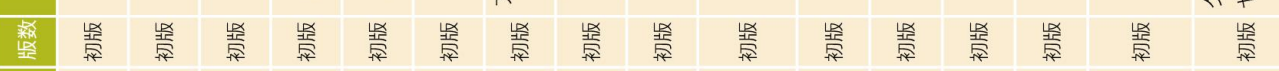

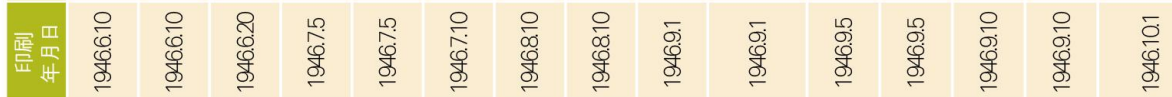

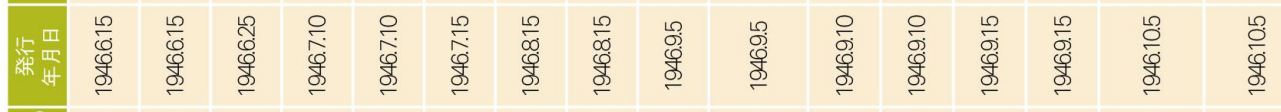

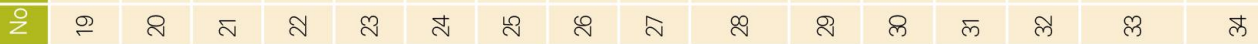




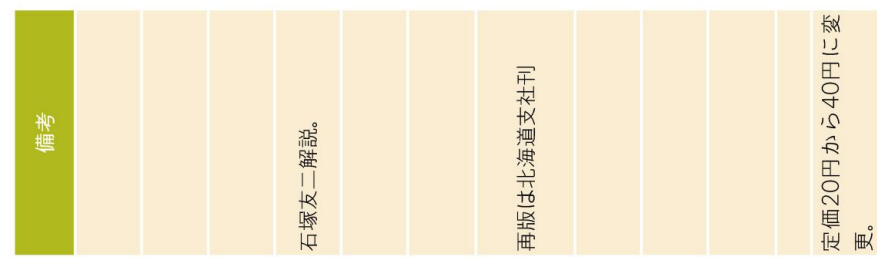

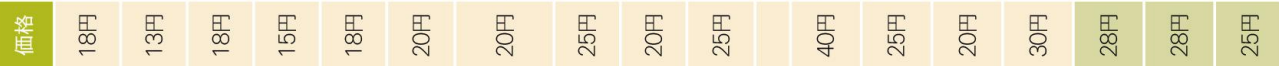

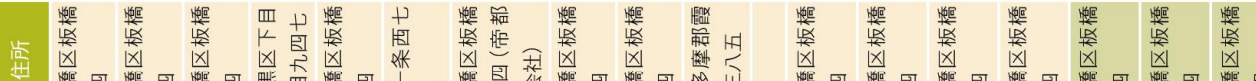

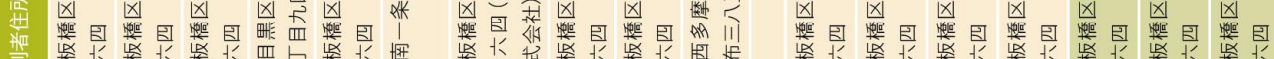

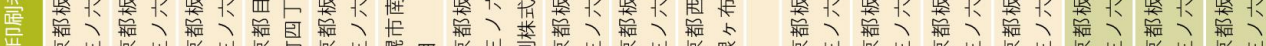

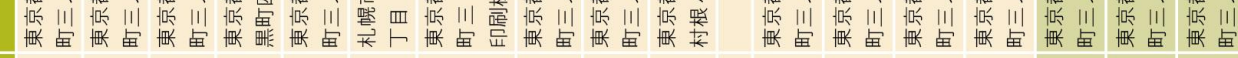

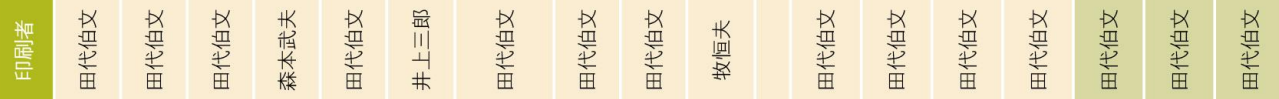

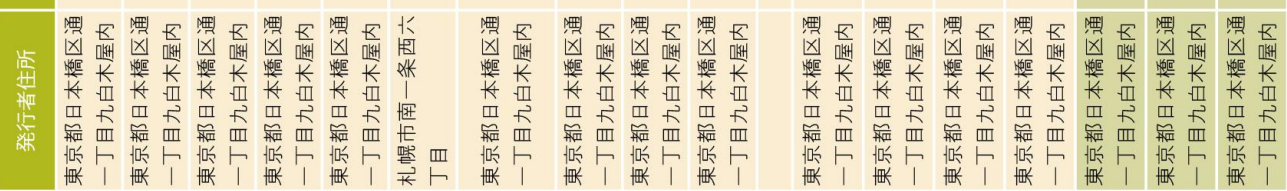

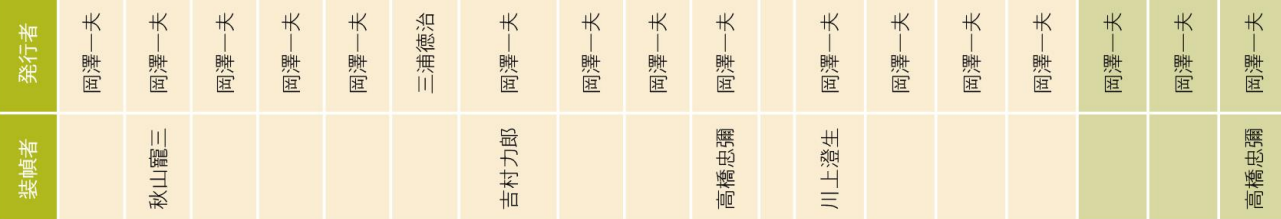

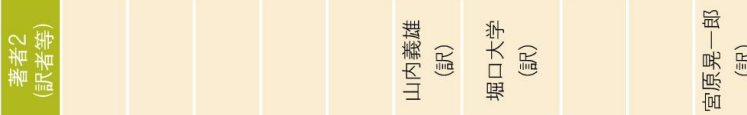

\begin{tabular}{|c|c|c|c|c|c|c|c|c|c|c|c|c|c|c|c|c|}
\hline 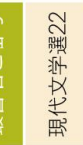 & & 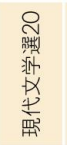 & & 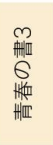 & 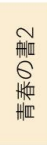 & & 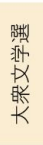 & 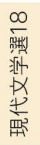 & 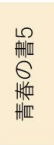 & 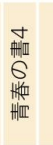 & & 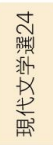 & & 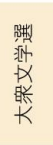 & 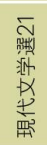 & 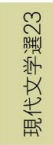 \\
\hline 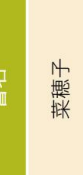 & 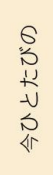 & $\begin{array}{l}6 \\
+9 \\
\frac{1}{+6}\end{array}$ & 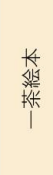 & 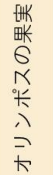 & 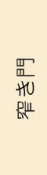 & 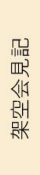 & 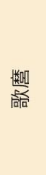 & 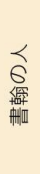 & 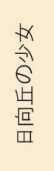 & 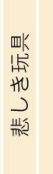 & $\begin{array}{l}\text { 重 } \\
\text { 业 }\end{array}$ & 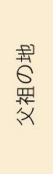 & 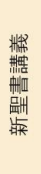 & 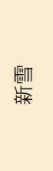 & 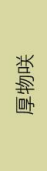 & 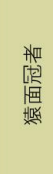 \\
\hline
\end{tabular}

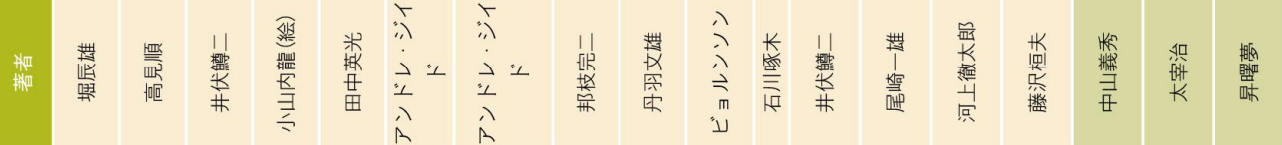

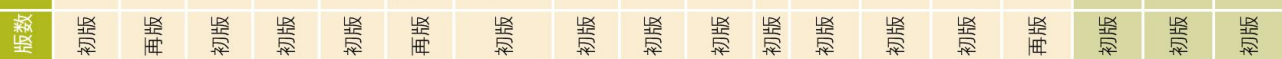

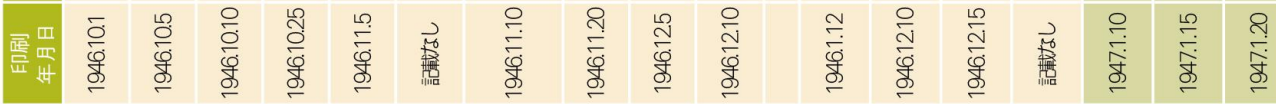

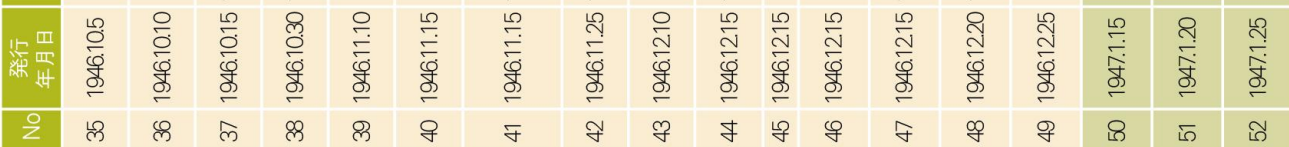




\begin{tabular}{|c|c|c|c|c|c|c|c|c|c|c|c|c|c|c|c|c|}
\hline 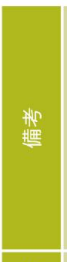 & & & & & & & & & & & & 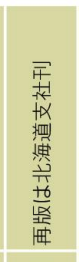 & 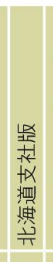 & 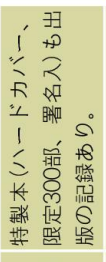 & & \\
\hline 路 & 롱 & $\frac{\mathrm{E}}{\frac{\mathrm{g}}{9}}$ & ్ㅡㅇ & $\stackrel{\text { 零 }}{N}$ & $\frac{\mathrm{F}}{8}$ & 歭 & 量 & 焉 & $\frac{5}{8}$ & 통 & $\frac{\mathbb{F}^{\circ}}{\infty}$ & 푱 & & 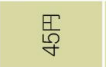 & $\underset{\infty}{5}$ & $\frac{7}{8}$ \\
\hline 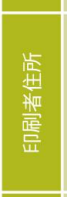 & 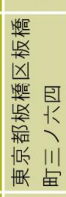 & 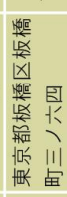 & 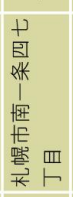 & 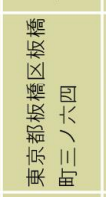 & 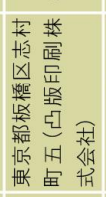 & 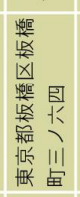 & 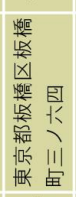 & 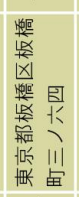 & 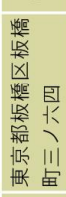 & 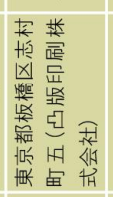 & 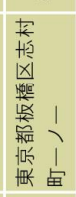 & 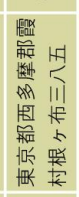 & & 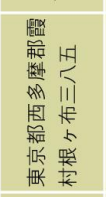 & 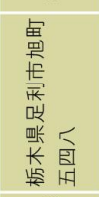 & 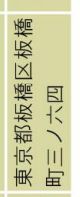 \\
\hline 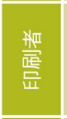 & 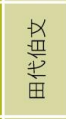 & 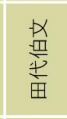 & 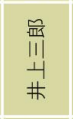 & 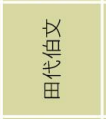 & $\begin{array}{l}\text { 织 } \\
\text { 哐 }\end{array}$ & 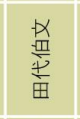 & 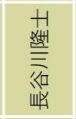 & 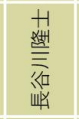 & $\begin{array}{l}\text { px } \\
\text { 监 } \\
\text { 吾 }\end{array}$ & 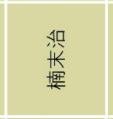 & 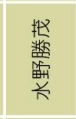 & 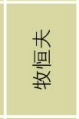 & & 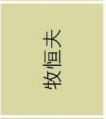 & $\begin{array}{l}\text { 篮 } \\
\text { 吉 } \\
\text { 骂 }\end{array}$ & 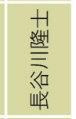 \\
\hline 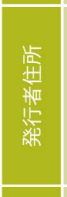 & 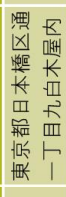 & 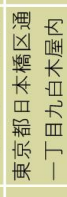 & 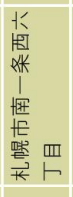 & 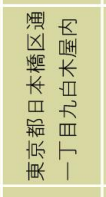 & 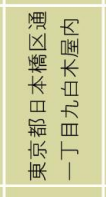 & 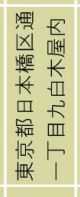 & 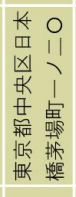 & 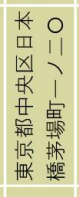 & 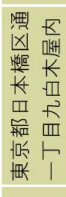 & 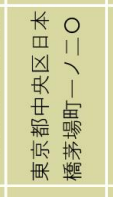 & 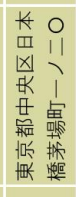 & 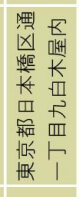 & & 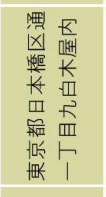 & 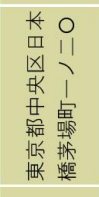 & 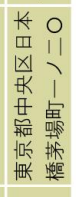 \\
\hline 就 & $\begin{array}{l}\text { K } \\
1 \\
\text { 盟 } \\
\text { 筐 }\end{array}$ & 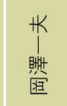 & 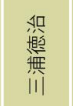 & 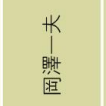 & 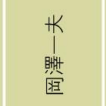 & $\begin{array}{l}K \\
\text { 畾 } \\
\text { 逼 }\end{array}$ & 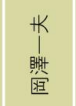 & 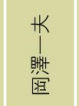 & $\begin{array}{l}K \\
1 \\
1 \\
\text { 偭 } \\
\end{array}$ & 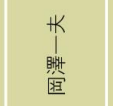 & $\begin{array}{l}K \\
1 \\
\text { 晆 } \\
\text { 道 }\end{array}$ & 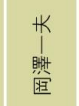 & & $\begin{array}{l}K \\
\text { 慒 } \\
\text { 道 }\end{array}$ & 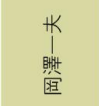 & $\begin{array}{l}K \\
\text { 盟 } \\
\text { 盟 }\end{array}$ \\
\hline 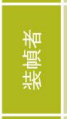 & & 蒿 & 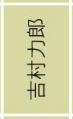 & & 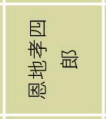 & & $\begin{array}{l}\text { K } \\
\text { 垹 } \\
\text { 罪 } \\
\text { 学 }\end{array}$ & 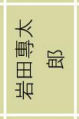 & 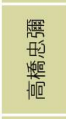 & & 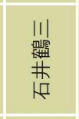 & 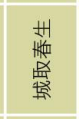 & & 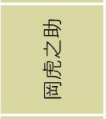 & & 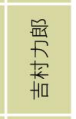 \\
\hline & & & 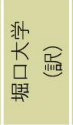 & 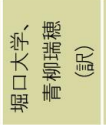 & & & & & 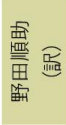 & & & & & & 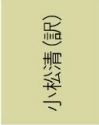 & \\
\hline 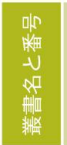 & 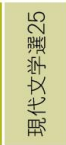 & 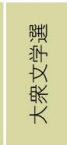 & & 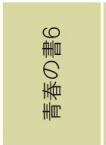 & & 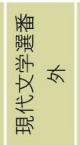 & 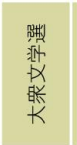 & 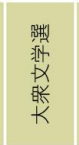 & 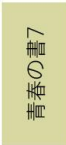 & & 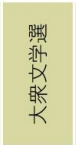 & & 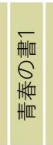 & & 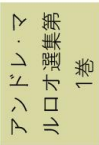 & \\
\hline offif & 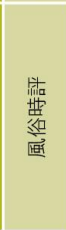 & 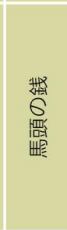 & 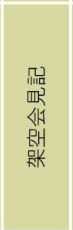 & 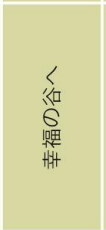 & 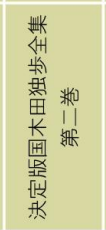 & 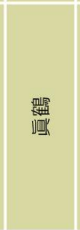 & 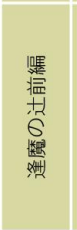 & 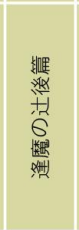 & $\begin{array}{l}\hat{\lambda} \\
\hbar \\
\bar{z} \\
\vdots \\
1 \\
y \\
\nu\end{array}$ & 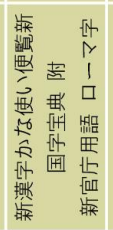 & 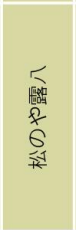 & 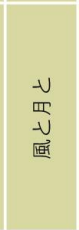 & 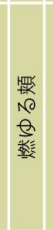 & 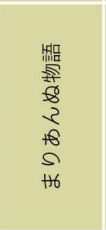 & $\begin{array}{l}\text { 䊉 } \\
\text { 監 }\end{array}$ & 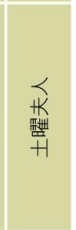 \\
\hline 槛 & 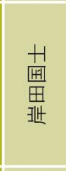 & 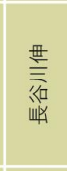 & 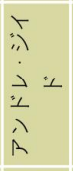 & 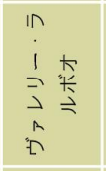 & 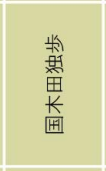 & 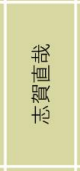 & 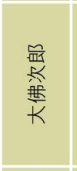 & 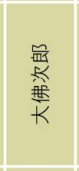 & $\begin{array}{l}\hat{\imath} \\
\hat{\imath} \\
\vec{t} \\
\vec{i} \\
\vec{\imath}\end{array}$ & 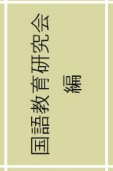 & 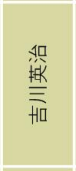 & 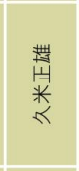 & 比齿 & $\begin{array}{l}\text { 侽 } \\
\text { 罚 } \\
\text { 晋 }\end{array}$ & 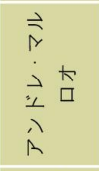 & 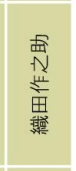 \\
\hline 塗 & 稀 & 崖 & $\begin{array}{l}\text { 畜 } \\
\text { 要 }\end{array}$ & 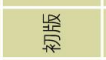 & 崖 & 紫 & 嘁 & 䅗 & 崖 & 京 & 若 & 崣 & 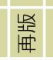 & 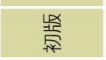 & 京 & 稀 \\
\hline 虚 & $\begin{array}{l}\stackrel{\llcorner}{N} \\
\stackrel{N}{\sigma}\end{array}$ & \begin{tabular}{l}
\multirow{2}{N}{} \\
స్
\end{tabular} & $\begin{array}{l}\frac{\delta}{m} \\
\stackrel{m}{0} \\
\dot{\sigma}\end{array}$ & $\begin{array}{l}\text { 을 } \\
\text { ले } \\
\text { హ. }\end{array}$ & $\begin{array}{l}\frac{\omega}{2} \\
\text { ले } \\
\frac{\sigma}{\sigma}\end{array}$ & 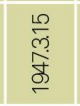 & $\begin{array}{l}\text { के } \\
\text { के } \\
\text { के }\end{array}$ & 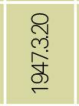 & 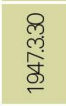 & 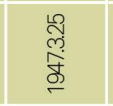 & 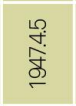 & 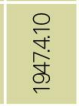 & & 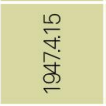 & 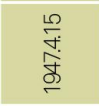 & \begin{tabular}{l}
8 \\
\multirow{2}{*}{} \\
\multirow{\sigma}{\sigma}{}
\end{tabular} \\
\hline 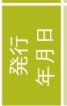 & $\begin{array}{l}\stackrel{0}{N} \\
\text { 함 }\end{array}$ & 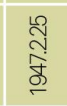 & $\begin{array}{l}\text { 을 } \\
\text { 항 }\end{array}$ & 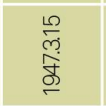 & 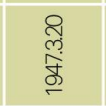 & 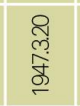 & 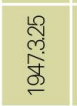 & 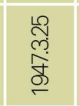 & 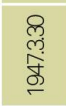 & 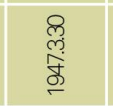 & 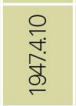 & $\begin{array}{l}\frac{L}{5} \\
\frac{10}{\sigma} \\
\frac{\sigma}{\sigma}\end{array}$ & 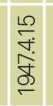 & 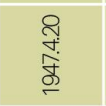 & \begin{tabular}{l}
8 \\
J \\
\multirow{0}{*}{} \\
\end{tabular} & 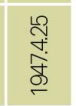 \\
\hline i & $\ddot{B}$ & 范 & 18 & 8 & 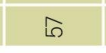 & 88 & 8 & 8 & $\bar{\varnothing}$ & 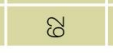 & 8 & ष & 8 & 8 & $\hat{0}$ & 88 \\
\hline
\end{tabular}




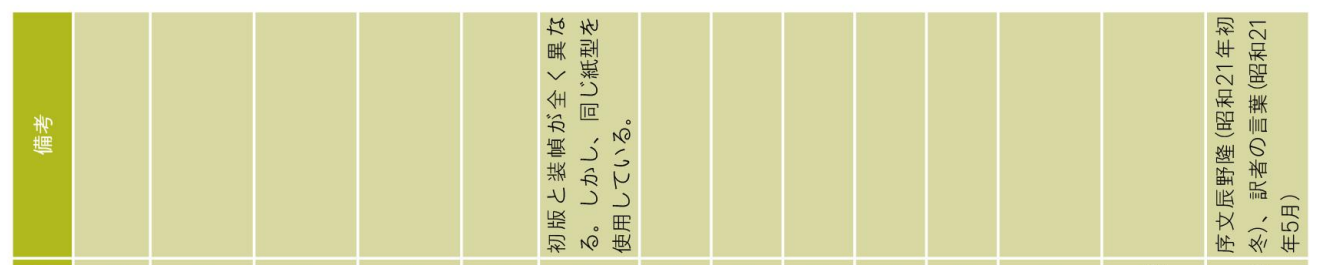

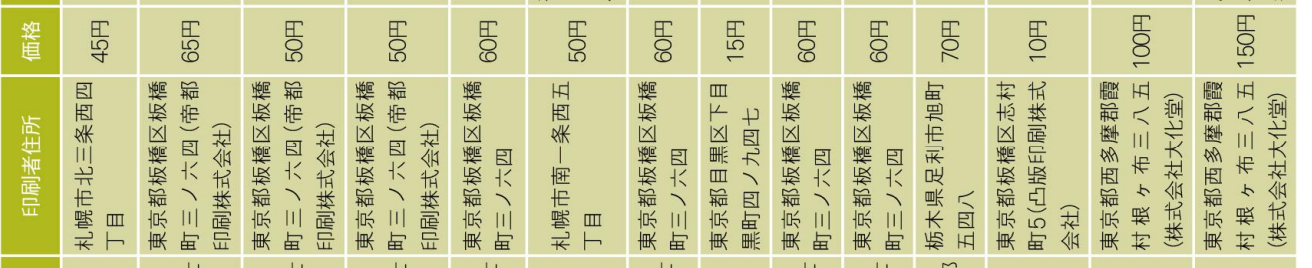

\begin{tabular}{|c|c|c|c|c|c|c|c|c|c|c|c|c|c|}
\hline 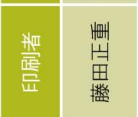 & 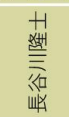 & 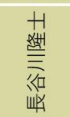 & 䖪 & 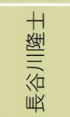 & 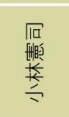 & 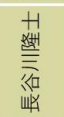 & 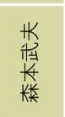 & 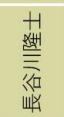 & 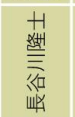 & $\begin{array}{l}\text { 㩊 } \\
\text { III } \\
\text { 哥 } \\
\text { 品 }\end{array}$ & $\begin{array}{l}\text { 梁 } \\
\text { 禁 }\end{array}$ & $\begin{array}{l}\text { K } \\
\frac{\text { IIII }}{\bar{w}}\end{array}$ & $\begin{array}{l}\frac{K}{K} \\
\frac{|l| l \mid l}{\bar{n}} \\
\end{array}$ \\
\hline 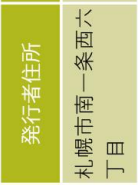 & 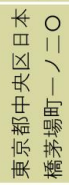 & 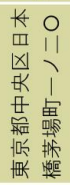 & 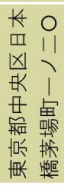 & 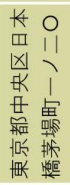 & 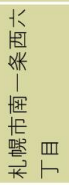 & 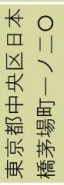 & 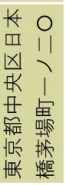 & 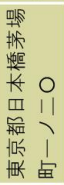 & 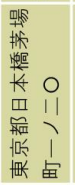 & 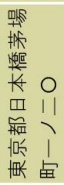 & 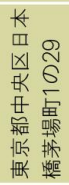 & 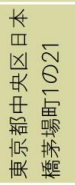 & 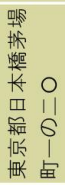 \\
\hline
\end{tabular}

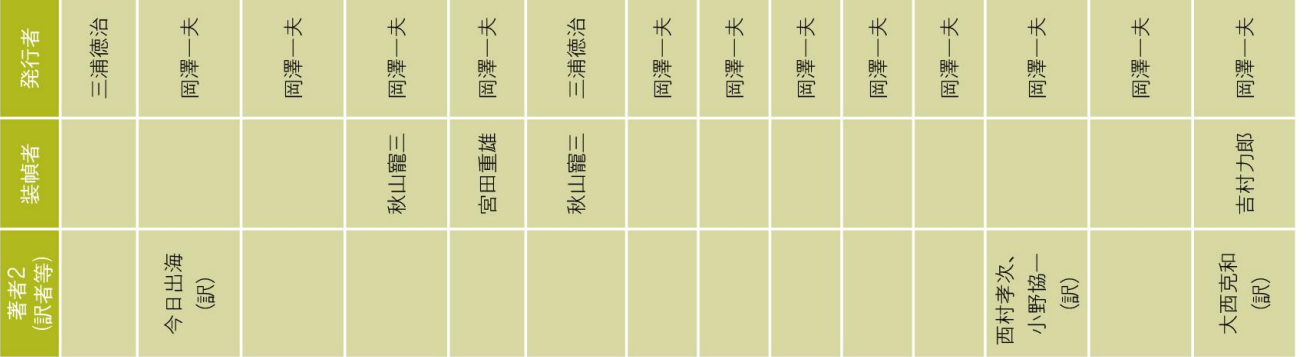

\begin{tabular}{|c|c|c|c|c|c|c|c|c|c|c|c|c|c|c|}
\hline 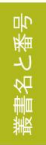 & & 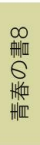 & 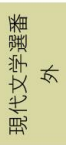 & & 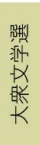 & & 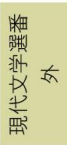 & & 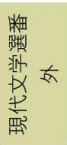 & 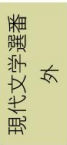 & 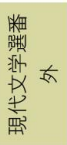 & 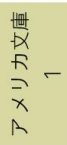 & & \\
\hline AfII & 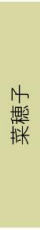 & 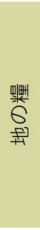 & $\begin{array}{l}\text { 蝍 } \\
\text { tit }\end{array}$ & 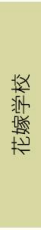 & 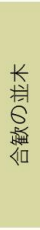 & 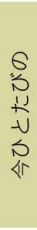 & 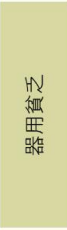 & 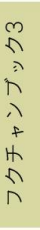 & 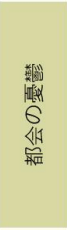 & $\begin{array}{l}\text { Tilid } \\
6 \\
\text { th } \\
\mathbb{a}\end{array}$ & 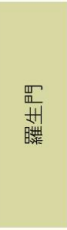 & 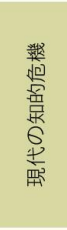 & 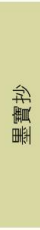 & 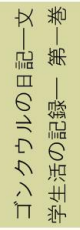 \\
\hline
\end{tabular}

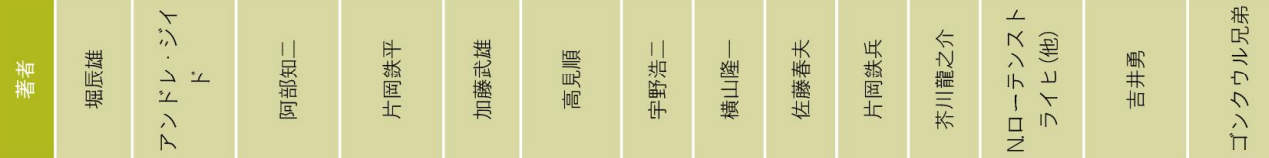

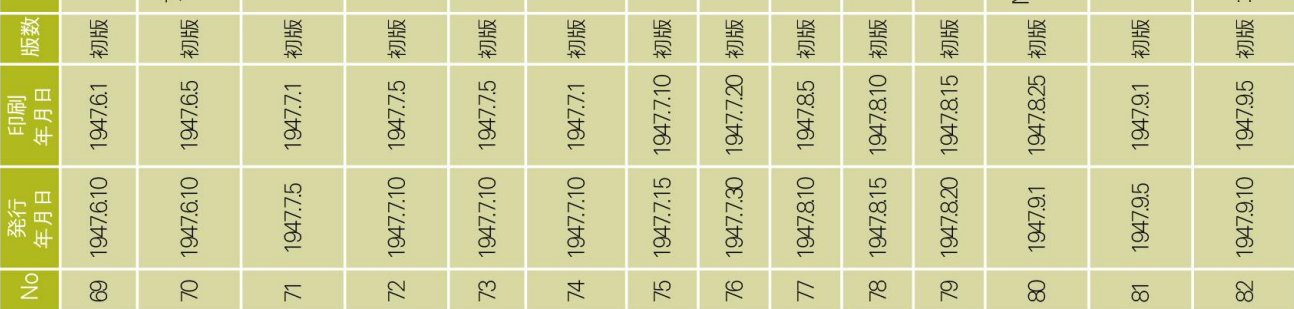




\begin{tabular}{|c|c|c|c|c|c|c|c|c|c|c|c|c|c|c|}
\hline 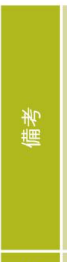 & & 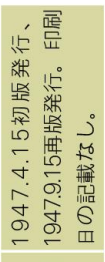 & & & & & 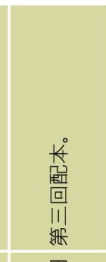 & & & & & & & 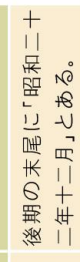 \\
\hline 锤 & $\begin{array}{l}\text { F } \\
\text { 음 }\end{array}$ & 퐁 & $\frac{\mathrm{F}}{8}$ & 퐁 & F & $\underset{8}{\bar{D}}$ & 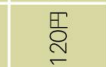 & $\frac{\mathrm{F}}{8}$ & $\frac{\pi}{2}$ & $\underset{\substack{\mathbb{N} \\
\infty}}{\mathbb{F}}$ & $\stackrel{\text { 蒠 }}{\leftarrow}$ & $\stackrel{\text { 통 }}{\leftarrow}$ & 풍 & 焉 \\
\hline 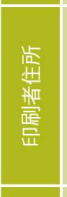 & 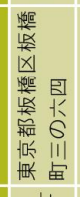 & 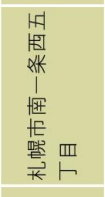 & 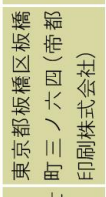 & 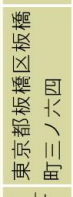 & 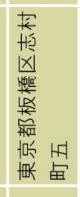 & 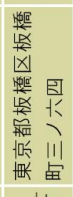 & 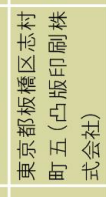 & 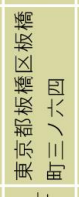 & 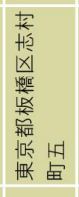 & 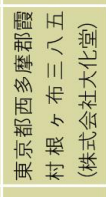 & 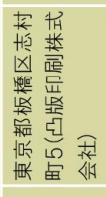 & 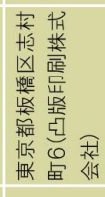 & 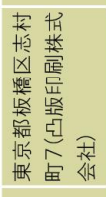 & 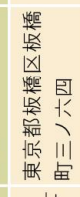 \\
\hline 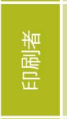 & 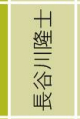 & 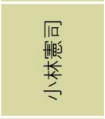 & 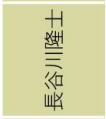 & 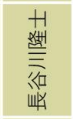 & $\begin{array}{l}\text { 喿 } \\
\text { 模 }\end{array}$ & 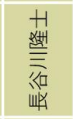 & $\begin{array}{l}\text { 哚 } \\
\text { 葉 }\end{array}$ & 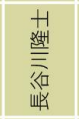 & $\begin{array}{l}\text { 雚 } \\
\text { 良 }\end{array}$ & $\begin{array}{l}\frac{K}{1} \\
\frac{101}{\sqrt{x}}\end{array}$ & 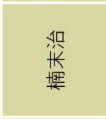 & 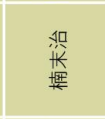 & 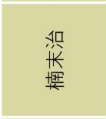 & 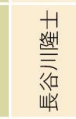 \\
\hline 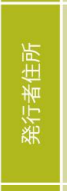 & 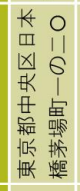 & 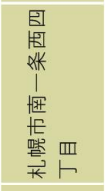 & 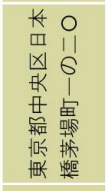 & 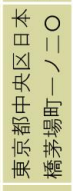 & 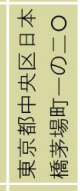 & 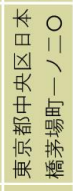 & 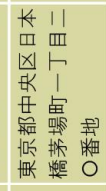 & 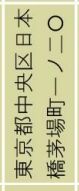 & 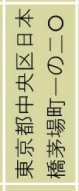 & 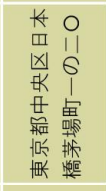 & 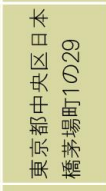 & 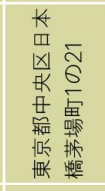 & 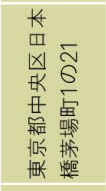 & 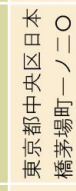 \\
\hline $\begin{array}{l}\text { 細 } \\
\text { 維 }\end{array}$ & 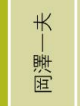 & 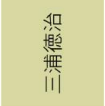 & $\begin{array}{l}\text { K } \\
\text { 䏹 } \\
\text { 蕰 }\end{array}$ & 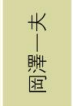 & $\begin{array}{l}\text { K } \\
\text { 盟 } \\
\text { 列 }\end{array}$ & 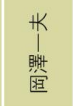 & $\begin{array}{c}K \\
1 \\
1 \\
\text { 齫 } \\
\end{array}$ & 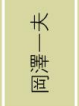 & $\begin{array}{l}K \\
\text { 䐎 } \\
\text { 盟 }\end{array}$ & $\begin{array}{l}* \\
\text { 盟 } \\
\text { 盟 }\end{array}$ & 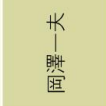 & $\begin{array}{l}\text { K } \\
\text { 盟 } \\
\end{array}$ & $\begin{array}{l}K \\
\text { K } \\
\text { 罪 } \\
\text { 道 }\end{array}$ & 罬 \\
\hline 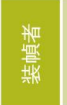 & 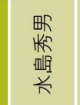 & 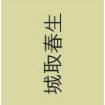 & 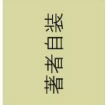 & 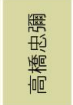 & & & $\begin{array}{l}\text { 易 } \\
\text { 蛪 } \\
\text { 通 }\end{array}$ & & 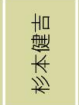 & & & & 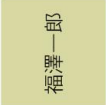 & \\
\hline 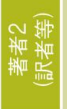 & & & & 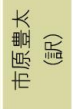 & & & & & & & 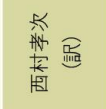 & & & \\
\hline 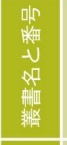 & & & & 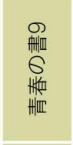 & & 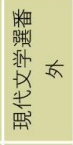 & & 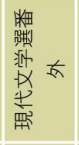 & & & 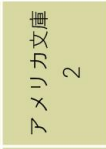 & 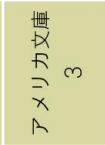 & & \\
\hline Afr & 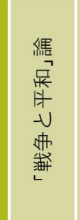 & $\begin{array}{l}-v \\
\text { 峒 } \\
\text { 画 }\end{array}$ & 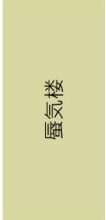 & 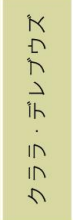 & 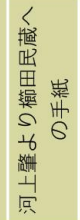 & 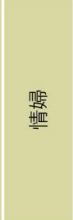 & 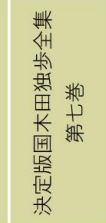 & 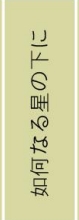 & 篦 & 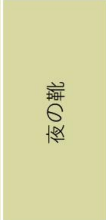 & 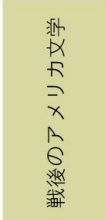 & 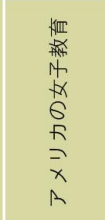 & 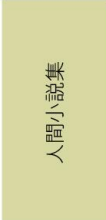 & 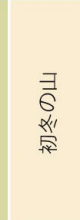 \\
\hline 斟 & 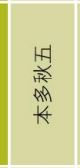 & 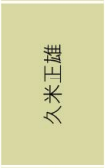 & 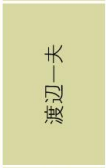 & 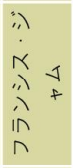 & 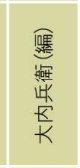 & 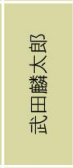 & 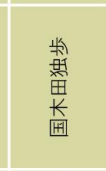 & 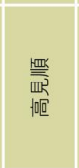 & 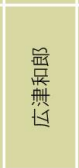 & $\begin{array}{l}\text { 粂 } \\
\text { 遇 }\end{array}$ & $\begin{array}{ll}\lambda & k \\
r & \lambda \\
1 & \hat{f} \\
1 & \\
A & < \\
z & \end{array}$ & 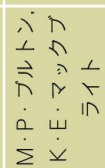 & 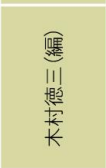 & 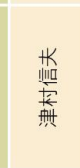 \\
\hline 整 & 崖 & $\frac{10}{10}$ & 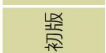 & 崖 & 綟 & 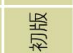 & 宸 & 祘 & 衤 & 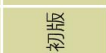 & 崖 & 㸚 & 唏 & 㟤 \\
\hline 霊焉 & 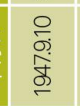 & 蜜 & 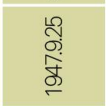 & 容 & $\begin{array}{l}\frac{10}{\check{\sigma}} \\
\stackrel{\circ}{\sigma} \\
\frac{\sigma}{\sigma}\end{array}$ & $\begin{array}{l}8 \\
\frac{8}{20} \\
\frac{0}{2}\end{array}$ & & & & 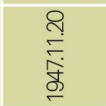 & & & & $\vec{x}$ \\
\hline 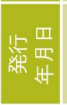 & $\begin{array}{l}\frac{\omega}{\sigma} \\
\sigma \\
\bar{\sigma} \\
\sigma\end{array}$ & 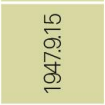 & $\begin{array}{l}8 \\
\text { ळ. } \\
\dot{\sigma} \\
\end{array}$ & 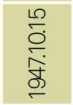 & 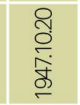 & 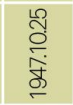 & 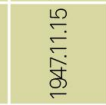 & 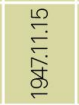 & 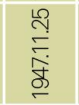 & 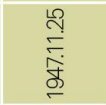 & $\begin{array}{l}\stackrel{8}{\leftrightarrows} \\
\stackrel{5}{\circ}\end{array}$ & & 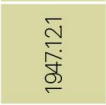 & \\
\hline z & 8 & ळ & $\llcorner 8$ & 8 & $\infty$ & $\infty 8$ & 8 & 8 & ऊ & के & В & あ & ८ & \\
\hline
\end{tabular}




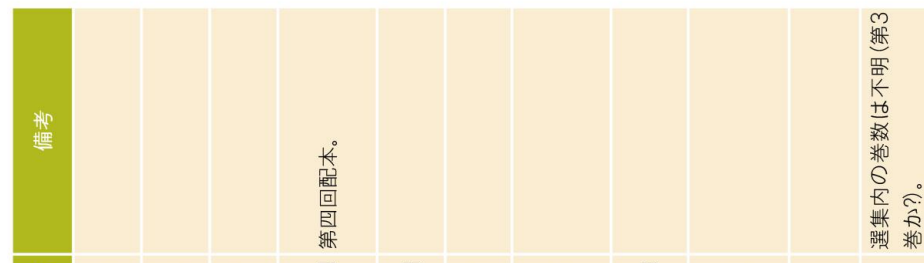

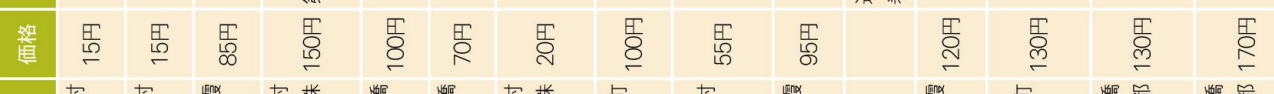

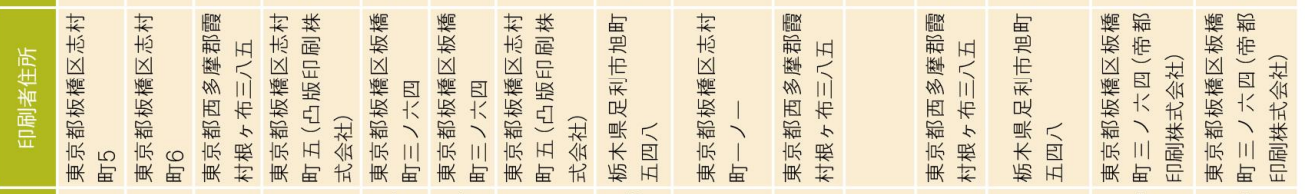

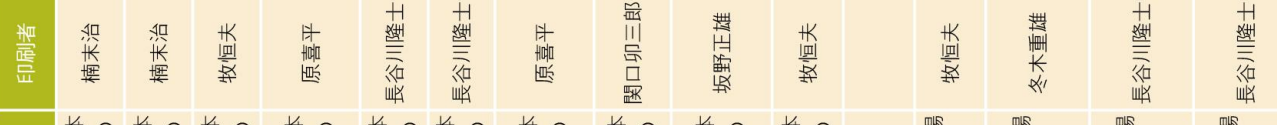

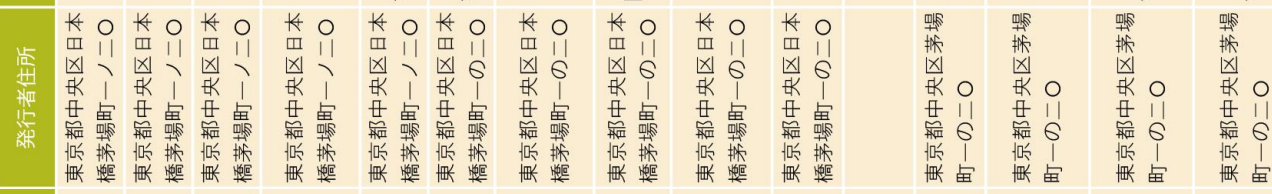

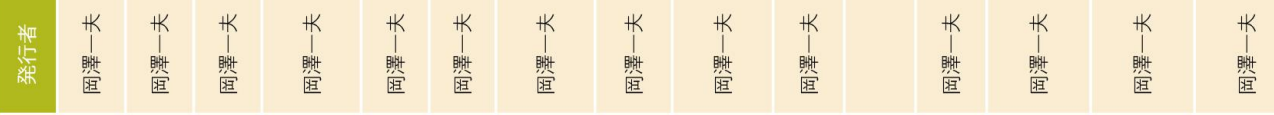

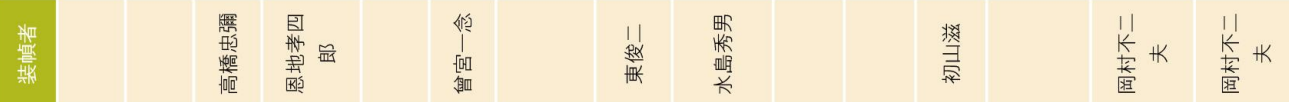

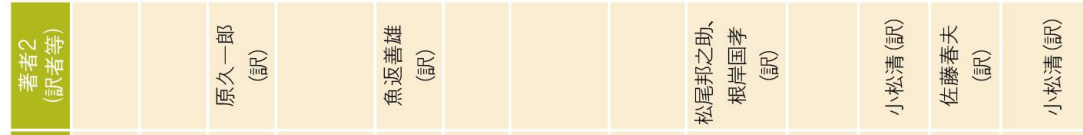

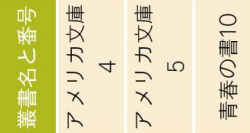

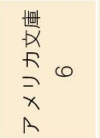

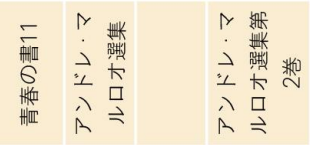

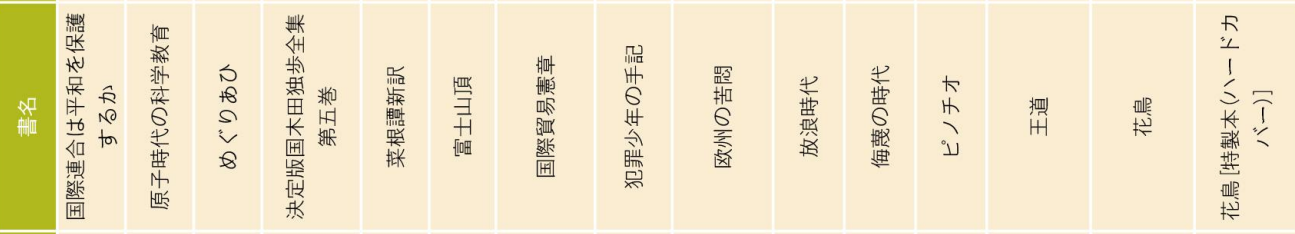

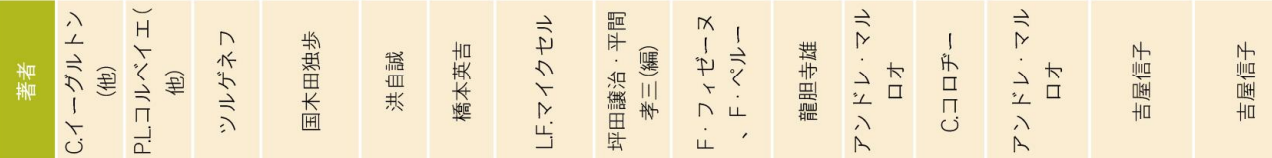

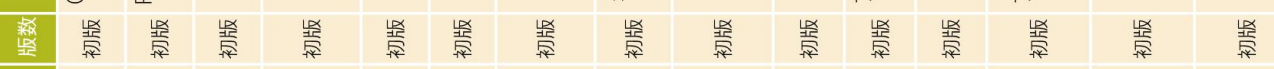

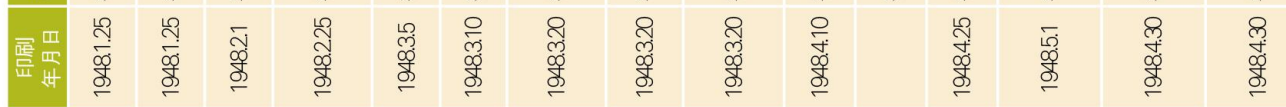

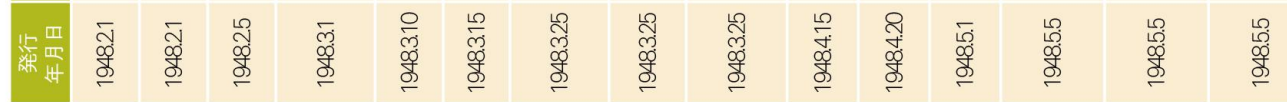

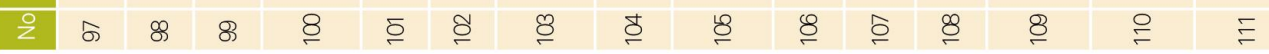




\begin{tabular}{|c|c|c|c|c|c|c|c|c|c|c|c|c|c|c|c|c|c|}
\hline 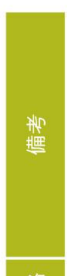 & & & & & 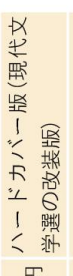 & & & & 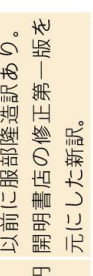 & 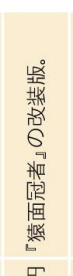 & & & & & & & \\
\hline 唯 & 픙 & $\underset{\text { F }}{\stackrel{\mathrm{O}}{\circ}}$ & 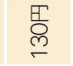 & & 통 & 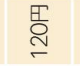 & 풍 & & 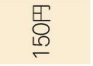 & 픔 & $\stackrel{\frac{\pi}{8}}{\underline{2}}$ & & & 풍 & $\stackrel{\text { 통 }}{\stackrel{\circ}{\circ}}$ & $\underset{\sigma}{\bar{g}}$ & 莺 \\
\hline 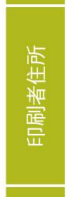 & 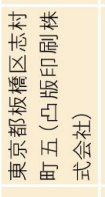 & 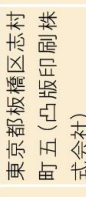 & 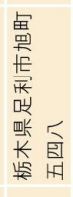 & & 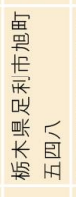 & 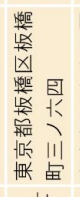 & 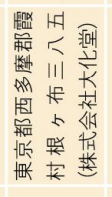 & & 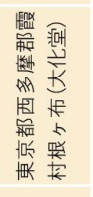 & 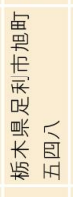 & 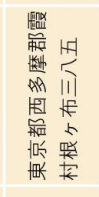 & & & 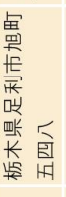 & 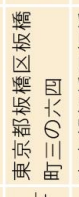 & 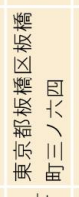 & 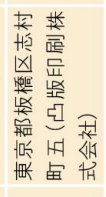 \\
\hline 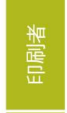 & 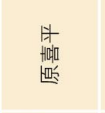 & 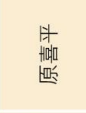 & 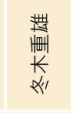 & & 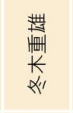 & 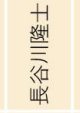 & 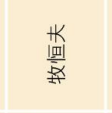 & & 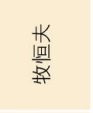 & 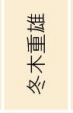 & 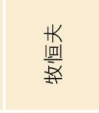 & & & 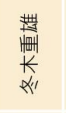 & 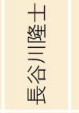 & 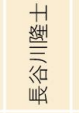 & 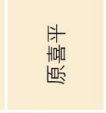 \\
\hline 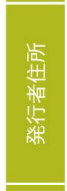 & 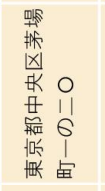 & 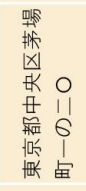 & 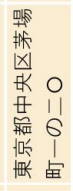 & & 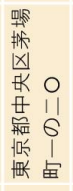 & 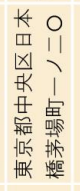 & 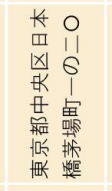 & & 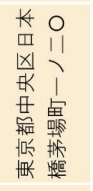 & 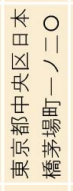 & 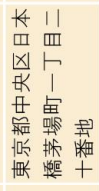 & & & 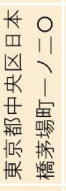 & 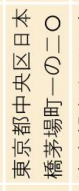 & 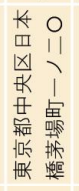 & 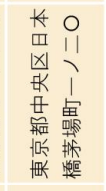 \\
\hline 把 & \# & K & K & & K & K & K & & K & K & K & & & K & \# & K & K \\
\hline 簿 & 㿡 & 盟 & 嗐 & & 琞 & 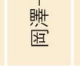 & 锖 & & 罡 & 琞 & 怔 & & & 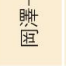 & 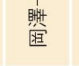 & 㘹 & 琞 \\
\hline 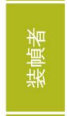 & & 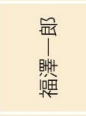 & 最 & & & & 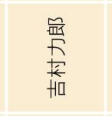 & & & 鶗 & 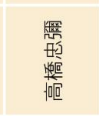 & & & & 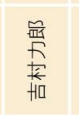 & & \\
\hline & & & & & & & 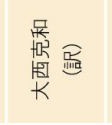 & & 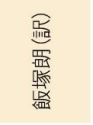 & & & & & & & & \\
\hline 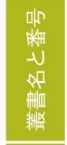 & 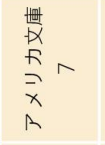 & 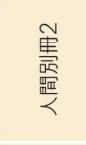 & & & & 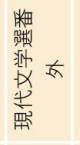 & & & 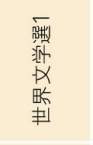 & & 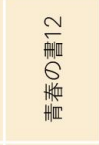 & & 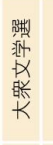 & & & 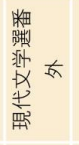 & 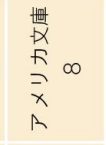 \\
\hline thin & 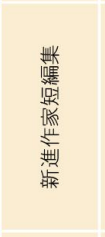 & 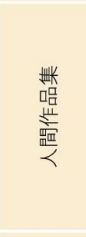 & 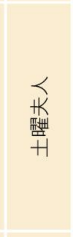 & 筁 & 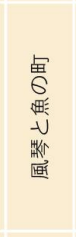 & 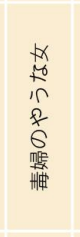 & 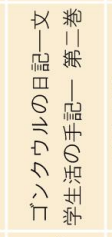 & 锓 & 抄 & 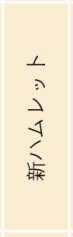 & $\begin{array}{l}\text { 带 } \\
\text { 菒 }\end{array}$ & 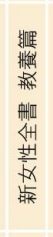 & 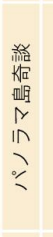 & 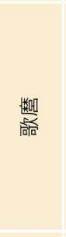 & 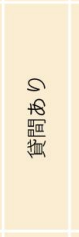 & $\begin{array}{l}\text { 凅 } \\
\text { 㗪 } \\
\text { W }\end{array}$ & 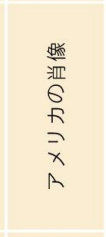 \\
\hline 被 & 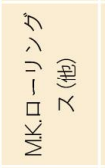 & 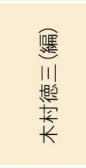 & 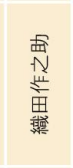 & 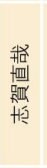 & 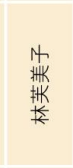 & 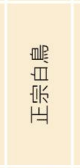 & 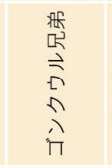 & 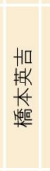 & $\begin{array}{l}\text { 㖼 } \\
\text { 而 }\end{array}$ & 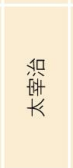 & 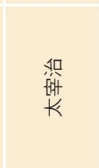 & 㯖 & 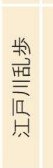 & 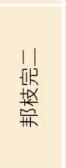 & 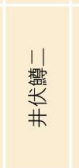 & 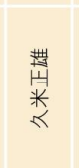 & 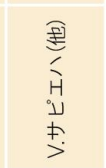 \\
\hline 整 & 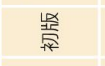 & 崖 & 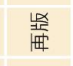 & 竖 & 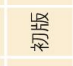 & 炭 & 宸 & $\begin{array}{l}\text { 偹 } \\
\end{array}$ & 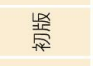 & 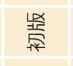 & 㟶 & 歮 & 竖 & 䡆 & 炭 & 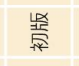 & 咷 \\
\hline 薷要 & 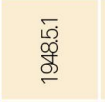 & 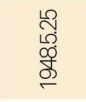 & 虚 & & 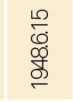 & $\begin{array}{l}8 \\
0 \\
0 \\
o ̛] \\
0\end{array}$ & 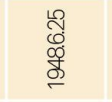 & & 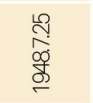 & $\begin{array}{l}\bar{\alpha} \\
\text { oj } \\
\bar{\sigma} \\
\sigma\end{array}$ & 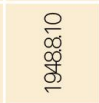 & & & 孛 & 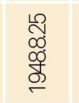 & 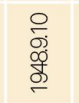 & $\begin{array}{l}\text { 응 } \\
\text { of } \\
\text { of } \\
\end{array}$ \\
\hline 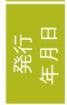 & 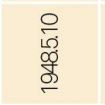 & $\begin{array}{l}\bar{o} \\
\text { og } \\
\bar{\sigma}\end{array}$ & $\begin{array}{l}10 \\
0 \\
0 \\
0 \\
\end{array}$ & 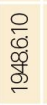 & $\begin{array}{l}8 \\
0 \\
o 0 \\
0 \\
0 \\
\end{array}$ & 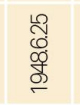 & $\begin{array}{l}8 \\
00 \\
o 0 \\
0 \\
\end{array}$ & $\begin{array}{l}8 \\
0 \\
00 \\
0 \\
0\end{array}$ & $\begin{array}{l}\bar{\alpha} \\
\text { of } \\
\bar{\sigma} \\
\sigma\end{array}$ & $\begin{array}{l}10 \\
\infty \\
o \\
0 \\
0 \\
\end{array}$ & $\begin{array}{l}\frac{L 0}{\sigma 0} \\
o g \\
\frac{\sigma 0}{\sigma} \\
\sigma\end{array}$ & 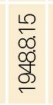 & $\begin{array}{l}8 \\
0 \\
o n \\
0 \\
0 \\
0\end{array}$ & $\begin{array}{l}8 \\
\infty \\
o 0 \\
o ̛ g \\
\end{array}$ & $\begin{array}{l}8 \\
o \\
o 0 \\
o ̛ ⿱ \\
\end{array}$ & 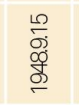 & $\begin{array}{l}\frac{10}{\sigma} \\
\stackrel{0}{\circ} \\
\frac{0}{\sigma} \\
\end{array}$ \\
\hline z & $\cong$ & $\stackrel{m}{\digamma}$ & $\stackrel{\Xi}{\rightleftarrows}$ & $\stackrel{\llcorner}{\rightleftharpoons}$ & $\stackrel{\circ}{\rightleftharpoons}$ & $£$ & $\stackrel{\infty}{=}$ & $\stackrel{9}{ }$ & $\stackrel{8}{-}$ & $\bar{ָ}$ & ฐ & $\stackrel{\Re}{\check{M}}$ & $\stackrel{\check{I}}{\check{S}}$ & $\stackrel{\leftrightarrow}{\sim}$ & $\nsubseteq$ & 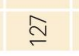 & $\stackrel{q}{\sim}$ \\
\hline
\end{tabular}




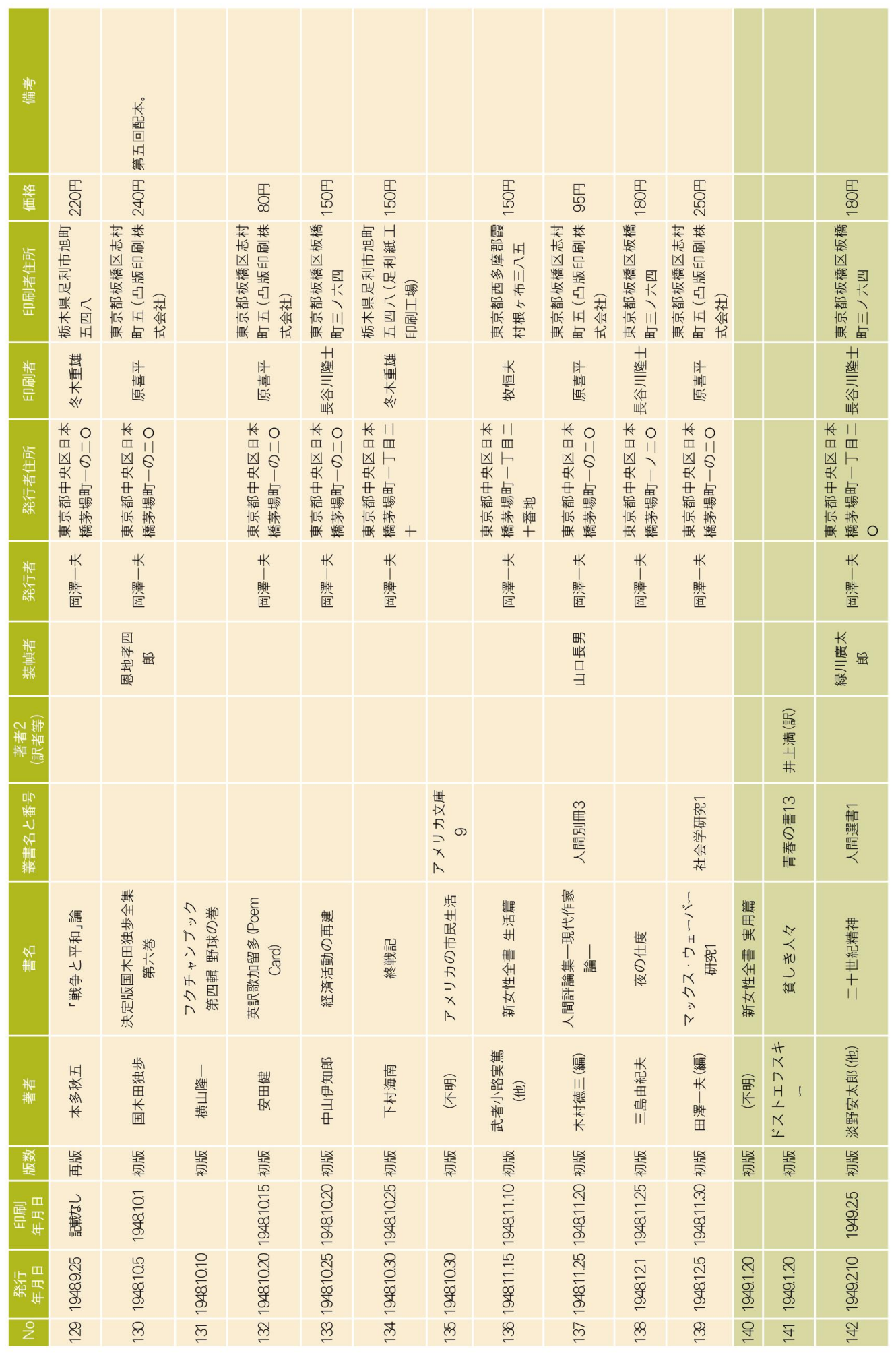




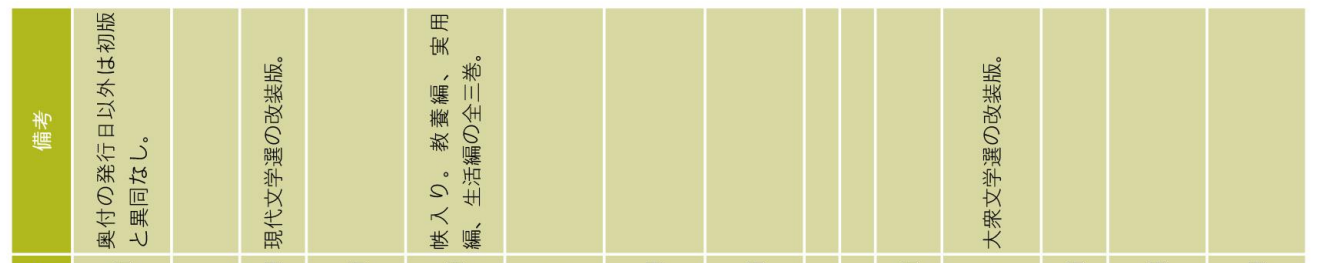

\begin{tabular}{|c|c|c|c|c|c|c|c|c|c|c|c|}
\hline 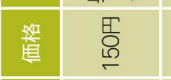 & $\stackrel{\text { 퐁 }}{\circ}$ & 퐁 & $\begin{array}{l}\text { F } \\
8 \\
\square\end{array}$ & $\underset{\infty}{\stackrel{F}{\infty}}$ & 풍 & $\begin{array}{l}\text { F } \\
\stackrel{\circ}{\infty}\end{array}$ & $\begin{array}{l}\underset{\Gamma}{\infty} \\
\stackrel{\infty}{\sigma}\end{array}$ & $\underset{\substack{\stackrel{5}{8} \\
\infty}}{\stackrel{F}{2}}$ & 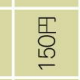 & $\underset{\sim}{\mathbb{D}}$ & 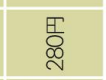 \\
\hline 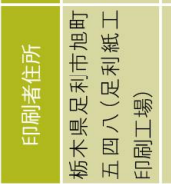 & 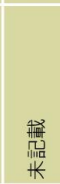 & 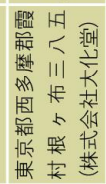 & 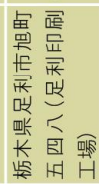 & 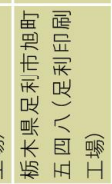 & 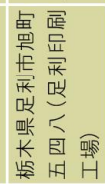 & 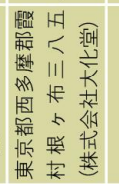 & 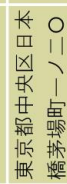 & 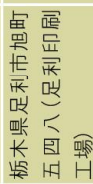 & 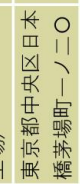 & 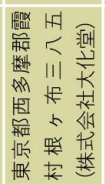 & 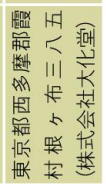 \\
\hline
\end{tabular}

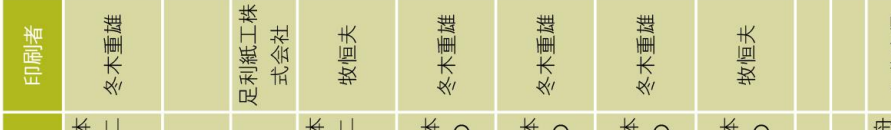

\begin{tabular}{|c|c|c|c|c|c|c|c|c|c|c|c|c|c|c|c|}
\hline 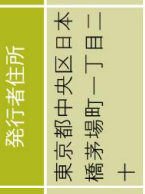 & 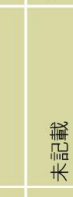 & 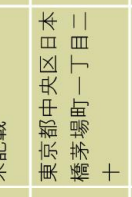 & 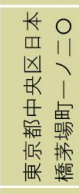 & 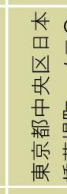 & & 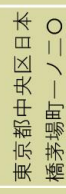 & & 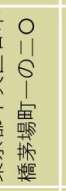 & & & & & 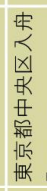 & & 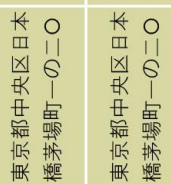 \\
\hline
\end{tabular}

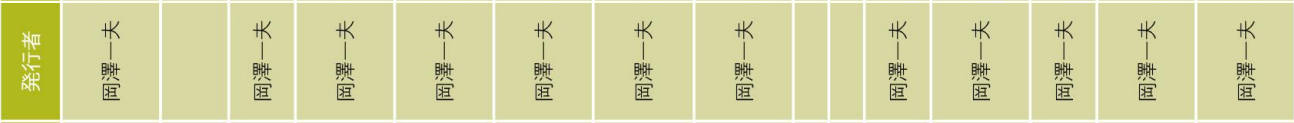

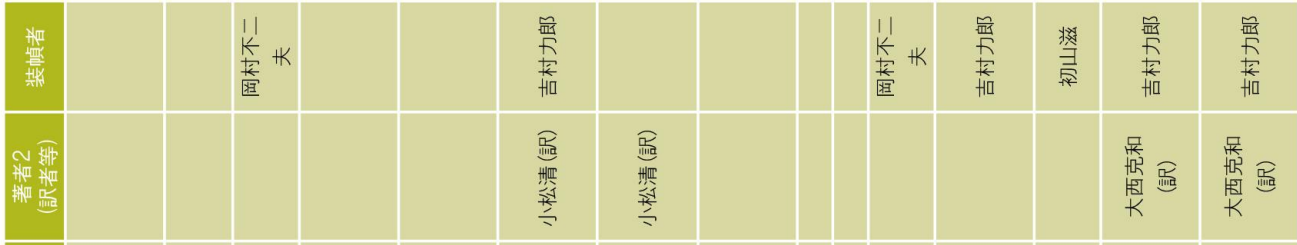

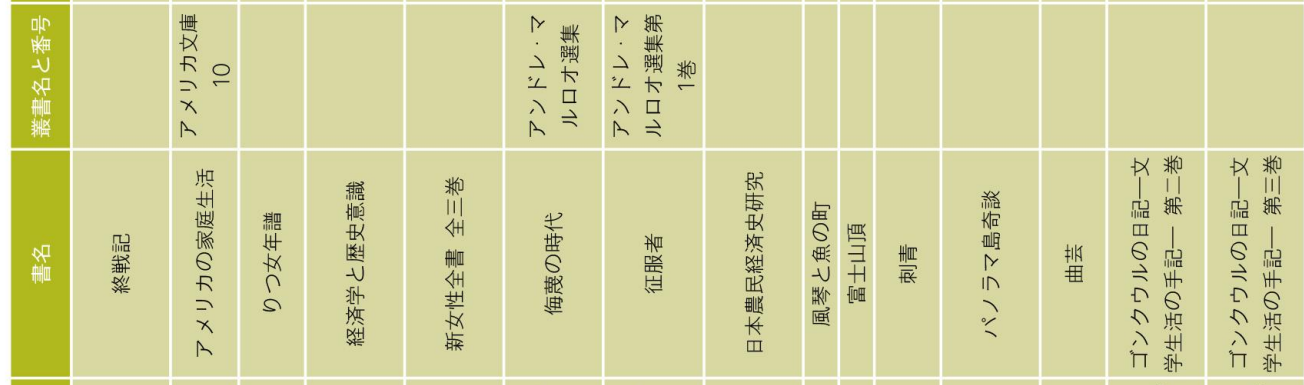

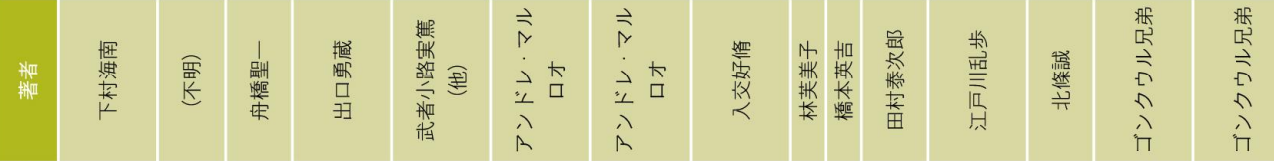

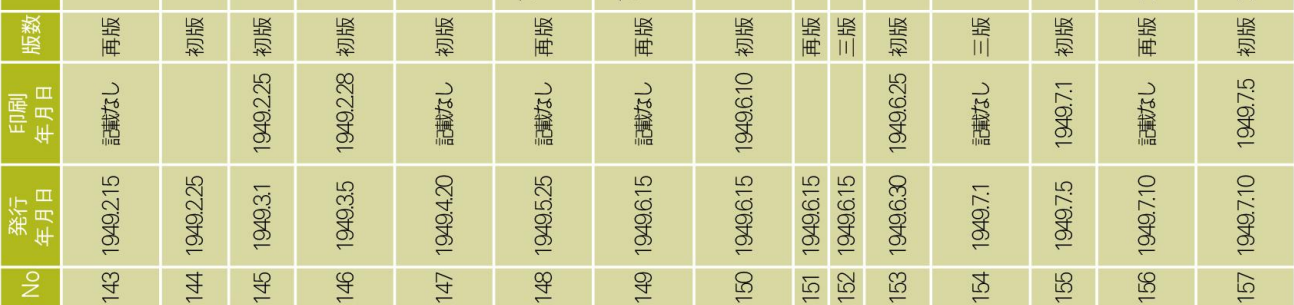




\begin{tabular}{|c|c|c|c|c|c|c|c|c|c|c|c|c|c|c|}
\hline 地地 & & & & & & & 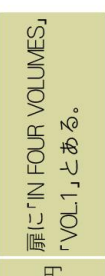 & & & & 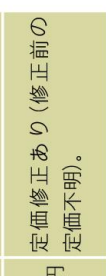 & 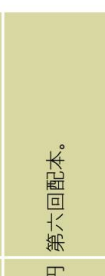 & $\begin{array}{l}\text { S } \\
\text { 僧 } \\
\end{array}$ & \\
\hline 檤 & 풍 & $\stackrel{\mathbb{F}}{\stackrel{\infty}{\infty}}$ & $\underset{8}{\mathbb{7}}$ & & $\stackrel{\text { E }}{\stackrel{\mathrm{O}}{\mathrm{B}}}$ & 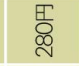 & 풍 & $\frac{\pi}{8}$ & 惒 & $\frac{\pi}{8}$ & $\stackrel{5}{\stackrel{5}{8}}$ & 殒 & $\begin{array}{l}\stackrel{F}{\circ} \\
\stackrel{\infty}{\leftarrow}\end{array}$ & $\begin{array}{l}\underset{\mathbb{E}}{\mathbb{O}} \\
\stackrel{\infty}{\leftarrow}\end{array}$ \\
\hline 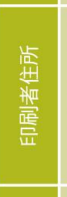 & 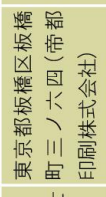 & 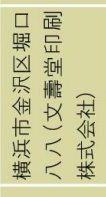 & 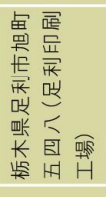 & & 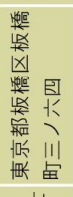 & 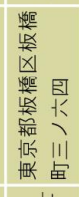 & 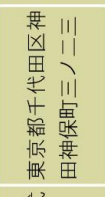 & 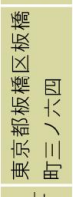 & 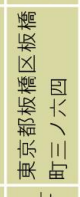 & 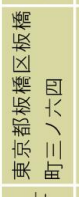 & 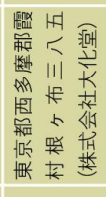 & 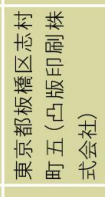 & 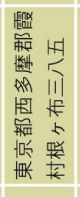 & 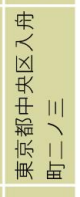 \\
\hline 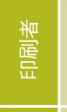 & 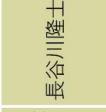 & 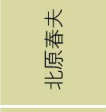 & 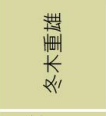 & & 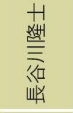 & 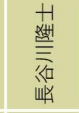 & 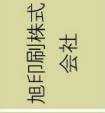 & 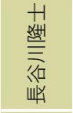 & 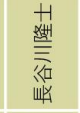 & 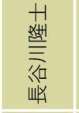 & 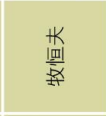 & 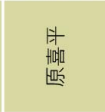 & 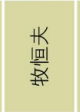 & 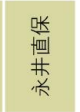 \\
\hline 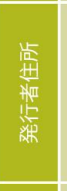 & 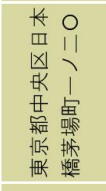 & 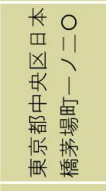 & 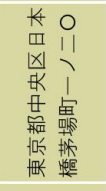 & & 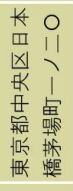 & 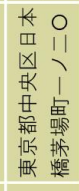 & 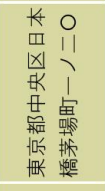 & 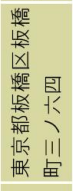 & 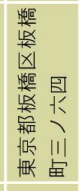 & 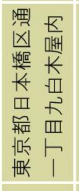 & 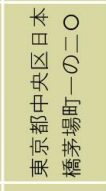 & 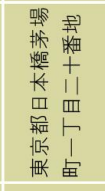 & 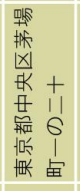 & 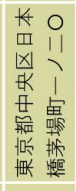 \\
\hline $\begin{array}{l}\text { 聇 } \\
\text { 澡 }\end{array}$ & 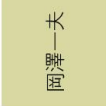 & 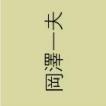 & 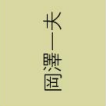 & & 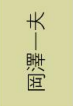 & 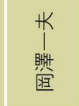 & $\begin{array}{c}\text { K } \\
\text { 罪 } \\
\text { 遂 }\end{array}$ & $\begin{array}{l}\text { K } \\
\text { 罪 } \\
\text { 童 }\end{array}$ & 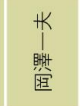 & 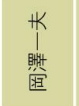 & 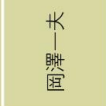 & 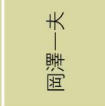 & $\begin{array}{l}K \\
\text { 盟 } \\
\text { 盟 }\end{array}$ & 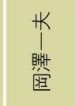 \\
\hline 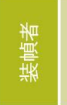 & 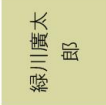 & & & & 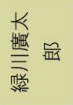 & 监监 & & 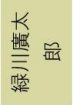 & 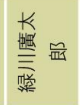 & 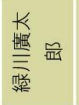 & 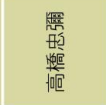 & 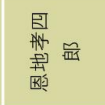 & & $\begin{array}{l}\text { 琞 } \\
\text { 至 }\end{array}$ \\
\hline 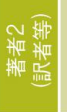 & 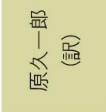 & & & 無 & & & & & & & 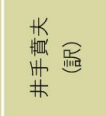 & & & \\
\hline 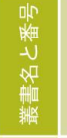 & & & & & 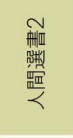 & 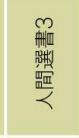 & 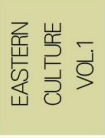 & 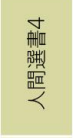 & 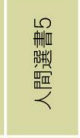 & 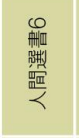 & 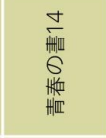 & & & \\
\hline 械 & 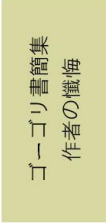 & 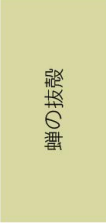 & 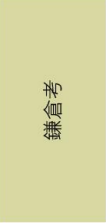 & 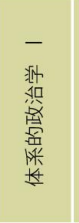 & 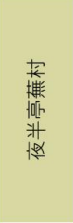 & 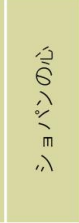 & 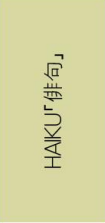 & 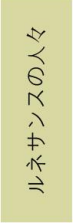 & 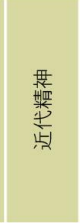 & 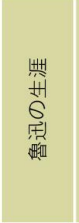 & 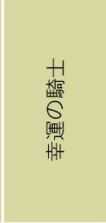 & 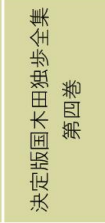 & 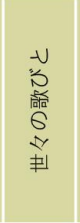 & 翟 \\
\hline 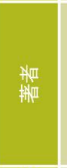 & $\begin{array}{l}\overrightarrow{3} \\
\frac{1}{1}\end{array}$ & 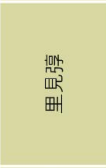 & 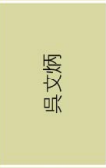 & 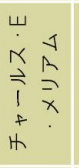 & 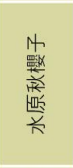 & $\begin{array}{l}\text { 梦 } \\
\text { 畨 } \\
\text { 遇 }\end{array}$ & 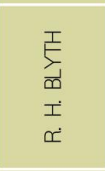 & 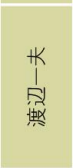 & 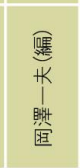 & 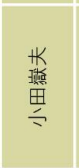 & 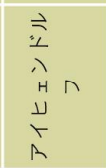 & 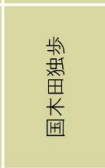 & 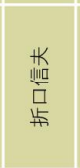 & $\begin{array}{l}\text { 紧 } \\
\text { 蛪 }\end{array}$ \\
\hline 餐 & 嗇 & 紫 & 啹 & 紫 & 装 & 装 & 紫 & 丵 & 䃙 & 装 & 㖺 & 㖺 & 紫 & 紧 \\
\hline 霊焉 & 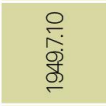 & 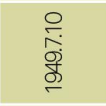 & 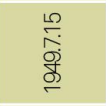 & & 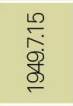 & 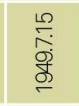 & 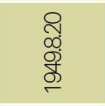 & $\begin{array}{l}\frac{10}{\circ} \\
\text { ơं } \\
\stackrel{\sigma}{\sigma}\end{array}$ & $\begin{array}{l}\frac{10}{\circ} \\
\stackrel{0}{\sigma} \\
\stackrel{\sigma}{\sigma} \\
\end{array}$ & $\begin{array}{l}\stackrel{\circ}{\circ} \\
\text { ơ } \\
\stackrel{\sigma}{\sigma}\end{array}$ & 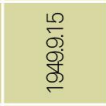 & 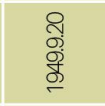 & 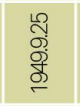 & $\begin{array}{l}\stackrel{8}{0} \\
0 \\
\text { oे } \\
\end{array}$ \\
\hline 維 $\frac{\mathrm{m}}{\mathrm{m}}$ & 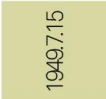 & 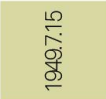 & 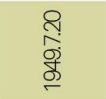 & 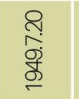 & 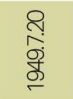 & 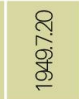 & $\begin{array}{l}\stackrel{2}{0} \\
o \\
o \\
o \\
\\
\end{array}$ & $\begin{array}{l}8 \\
\text { के } \\
\text { Jै }\end{array}$ & $\begin{array}{l}8 \\
\text { Oे } \\
\text { ơ } \\
\end{array}$ & $\begin{array}{l}8 \\
\text { ô } \\
\text { do } \\
\text { de }\end{array}$ & $\begin{array}{l}8 \\
\text { के } \\
\text { ơ } \\
\end{array}$ & 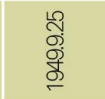 & 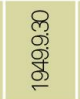 & 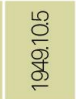 \\
\hline z & $\stackrel{\infty}{\stackrel{\infty}{\sim}}$ & $\stackrel{g}{\stackrel{8}{口}}$ & 8 & $\Phi$ & 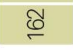 & $\mathscr{8}$ & $\underset{\Xi}{\Phi}$ & $\stackrel{\bullet}{\sigma}$ & $\underset{-8}{8}$ & $\emptyset$ & $\stackrel{8}{\circ}$ & $\stackrel{8}{\square}$ & $\stackrel{?}{\leftarrow}$ & $\Sigma$ \\
\hline
\end{tabular}

